\title{
Stock Repurchases and Executive Compensation Contract Design: The Role of Earnings per Share Performance Conditions
}

\author{
Steven Young \\ Lancaster University Management School \\ Jing Yang \\ Towers Perrin
}

\begin{abstract}
We examine the link between firms' stock repurchase activity and the presence of earnings per share (EPS) performance conditions in executive compensation contracts. Findings reveal a strong positive association between repurchases and EPS-contingent compensation arrangements. Further analysis suggests net benefits to shareholders from this association. Specifically, repurchasers experience larger increases in total payouts; the positive association between repurchases and cash performance is more pronounced for firms with EPS targets in the presence of surplus cash; undervalued firms with EPS targets are more likely to signal mispricing through a repurchase; and repurchasers with EPS conditions are associated with lower abnormal accruals. We find no evidence that EPS-driven repurchases impose costs on shareholders in the form of investment myopia.
\end{abstract}

Keywords: corporate payout policy; performance targets; earnings management; efficient contracting.

Data Availability: The data are available from public sources identified in the study.

\footnotetext{
We are indebted to Paulo Alves for excellent research support. We are also grateful for the insightful suggestions and support offered by two anonymous reviewers. Helpful comments and suggestions were also provided by Amir AmelZadeh, Mary Ellen Carter, John Forker, Stephen X. H. Gong, Marwan Izzeldin, Mike Jones, Steven Kachelmeier (editor), and seminar participants at the University of Bath, University of Bristol, ESSEC, University of Mannheim, Stockholm School of Economics, the 2009 Annual Meeting of the American Accounting Association, the 2009 European Financial Management Symposium on Corporate Governance and Control, the 2007 Annual Meeting of the British Accounting Association, and the 2006 and 2009 Financial Reporting and Business Communication Conferences. Financial support was provided by The Leverhulme Trust (Project F/00185/I).
}

All opinions expressed herein are attributable solely to the authors and in no way reflect the views of Towers Perrin.

Editor's note: Accepted by Steven Kachelmeier.

Submitted: October 2008

Accepted: August 2010

Published Online: March 2011 


\section{INTRODUCTION}

7 his study investigates the link between firms' stock repurchase activity and the presence of earnings per share performance conditions in executive compensation contracts. Our analysis seeks to address the apparent disconnect between theory and practice regarding repurchases. One the one hand, traditional academic theories identify factors such as signaling (Vermaelen 1981), agency costs (Fenn and Liang 2001), and leverage (Dittmar 2000) as important determinants of repurchase activity. On the other hand, survey and anecdotal evidence highlight earnings per share (EPS) as a key factor influencing managers' repurchase decisions (Badrinath and Varaiya 2000; Brav et al. 2005; Caster et al. 2006). Exploring why managers attach such weight to the EPS impact of repurchases represents an important step toward a better understanding of this increasingly significant aspect of payout policy.

Recent research sheds light on the links between repurchase decisions and EPS-related considerations. Kahle (2002), Bens et al. (2002), and Bens et al. (2003) focus on the dilutive impact of employee stock options (ESOs). Their findings suggest repurchases are a managerial response to EPS dilution concerns. Evidence also suggests that managers use repurchases for benchmarkbeating purposes, including meeting or exceeding analysts' EPS forecasts (Hribar et al. 2006), preserving a sequence of EPS improvement (Myers et al. 2007), and maintaining historic EPS growth rates (Bens et al. 2003).

Our analysis builds on prior research by examining whether managers' stock repurchase decisions are sensitive to explicit EPS-related incentives provided by executive compensation contracts. Compensation contracts linking rewards to EPS performance provide executives with direct and potentially powerful incentives to manage reported EPS. We therefore test whether repurchase activity is higher for firms with executive compensation tied to EPS performance.

Empirical tests employ data for a comprehensive sample of U.K. nonfinancial firms over the period January 1998 through December 2006. Several features make the U.K. a particularly attractive setting in which to explore the link between repurchases and compensation contract design. First, in addition to executive bonus plans that routinely condition rewards on EPS performance, executives' long-term incentives including options and restricted stock frequently employ EPS vesting conditions (Conyon et al. 2000; Carter et al. 2009). Second, regulatory restrictions governing the treatment of repurchases during the majority of our sample period help simplify empirical tests by tempering the link between repurchase activity and the dilutive effects of ESOs. In particular, U.K. Company Law required repurchased shares to be cancelled immediately rendering repurchases a costly device for offsetting ESO-related EPS dilution (because issuing new shares is administratively more costly than reissuing treasury stock). Instead, U.K. firms with ESO programs typically established a wholly owned trust company to repurchase (and reissue) shares on their behalf. Under U.K. GAAP, shares held by ESO trusts are excluded from the EPS calculation until shares vest unconditionally. Since ESO shares are purchased solely to fund share-based compensation plans and because ESO purchases do not meet the legal definition of a stock repurchase, our tests can distinguish between repurchases driven by dilution concerns (ESO shares) and repurchases driven by other factors. ${ }^{1}$

Findings reveal a significant association between repurchase activity and the presence of EPS-based compensation arrangements. The predicted odds of a repurchase for firms for which

\footnotetext{
1 U.K. Company Law was amended in December 2003 to allow firms to hold repurchased shares as treasury stock. Consistent with the absence of ESO-related motives for repurchases, none of our sample firms mentioned the dilutive impact of stock-based compensation plans among the list of repurchase reasons disclosed in their annual reports prior to this date. Following the regime switch, most U.K. firms continue to cancel repurchased shares. As described in Section III, we exclude from our subsequent empirical tests firms that explicitly repurchase stock into treasury post-December 2003 to fund option plans.
} 
executive compensation depends on EPS performance are almost twice the level observed for firms for which rewards are independent of EPS. EPS conditions in bonus and option plans are associated with incrementally significant effects. Our findings suggest that EPS performance conditions represent an important determinant of U.K. managers' stock repurchase decisions.

An important ancillary question raised by our findings is how the link between repurchases and executive compensation arrangements impacts shareholder value. We explore this issue by examining the costs and benefits associated with compensation-driven repurchases. On balance, our evidence suggests that EPS-driven repurchases yield net benefits to shareholders. First, repurchasers make higher aggregate payouts to shareholders regardless of the performance conditions employed in executive compensation contracts, and we find no evidence that EPS-driven repurchase payouts occur at the expense of either investment myopia (Bens et al. 2002) or dividend substitution (Grullon and Michaely 2002). Second, tests reveal several contracting benefits from repurchase incentives caused by linking compensation to EPS performance, including a stronger association between cash performance and repurchases in the presence of surplus cash, a higher propensity to signal undervaluation through a repurchase when stock price falls below intrinsic value, and lower accrual manipulation.

Our study contributes to prior research in several ways. First, while extant work links repurchases to the dilutive impact of employee option plans (Kahle 2002; Bens et al. 2002; Bens et al. 2003), and EPS-based bonus plans to the dilutive impact of new equity issues (Huang et al. 2010), the association between repurchase activity and EPS-contingent compensation has attracted little attention. Our study highlights EPS-based executive compensation contracts as an important determinant of repurchase activity that is entirely consistent with the EPS benefits of buybacks frequently highlighted by management (Badrinath and Varaiya 2000; Brav et al. 2005; Caster et al. 2006). Our findings complement and extend Marquardt et al.'s (2009) evidence that EPS-based bonus plans explain managers' preference for accelerated stock repurchases over regular open market buybacks. We add to their findings by demonstrating that EPS-based compensation arrangements also explain the underlying decision to repurchase stock and that shareholders benefit from this relation. Second, our analysis relates to work on performance measure choice in compensation contracts. In particular, prior research emphasizes how EPS targets encourage overinvestment (Brealey et al. 2008, 889). Our results provide a counterbalance to this view by highlighting how the repurchase incentives created by EPS-contingent pay help align managers' interests with those of shareholders. Our conclusion is consistent with Huang et al. (2010) who model the use of EPS conditions in executive bonus plans and find that EPS-contingent compensation helps resolve agency problems by protecting current shareholders from a reduction in proportional ownership. Our analysis also contributes to the small body of research exploring the interaction between alternative earnings management instruments (e.g., Demski et al. 2004; Cohen et al. 2008). We argue that shareholders gain when managers manipulate EPS through repurchases rather than accounting accruals, and we show that the incentive created by EPS targets to manipulate via repurchases correlates with less accrual management.

Section II develops the link between repurchases and executive compensation arrangements, and reviews the structure of executive compensation plans in the U.K. Section III provides details of our sample, data, and research design. Section IV reports results of tests that examine the association between repurchases and EPS-based performance targets in executive compensation plans. Section V explores the implications for shareholders of repurchases motivated by EPScontingent performance conditions. Section VI concludes. 


\section{LITERATURE REVIEW AND INSTITUTIONAL OVERVIEW Stock Repurchases, Earnings Management, and Executive Compensation}

Despite being overlooked in much of the corporate payout policy literature, managers and financial commentators have long recognized the EPS implications of stock repurchases. The impact of repurchases on reported EPS represents the net of both numerator and denominator effects. The numerator effect, which works to reduce EPS, represents the decline in earnings caused by an increase in borrowing (for repurchases financed with debt) or a reduction in investment returns (for repurchases financed using cash reserves). The denominator effect serves to increase EPS by reducing the number of shares outstanding. Repurchases have a positive net effect on EPS for firms whose earnings-to-price ratio exceeds the opportunity cost of funds (i.e., either the after-tax return on short-term cash investments or the cost of debt; Guay 2002; Bens et al. 2003; Hribar et al. 2006). Survey evidence reported by Brav et al. (2005) highlights the central role EPS considerations play in shaping managers' repurchase decisions, with three-quarters of senior executives citing EPS growth as an important factor affecting their repurchase decisions.

Research has begun to explore the link between repurchases and EPS in several contexts. One EPS-related factor predicted to motivate repurchases is earnings dilution caused by ESO plans. Accretive stock repurchases can offset the dilutive effects of ESOs on reported EPS in several ways. For example, while ESO exercises reduce basic EPS by increasing the weighted average number of shares outstanding for the period, managers can mitigate this dilution by repurchasing shares to fund option exercises. Bens et al. (2002) and Kahle (2002) present evidence consistent with this option-funding hypothesis. Conversely, Bens et al. (2003) conclude that repurchases are not a response to the dilutive impact of option exercises on basic EPS. Instead, their results suggest the link between repurchases and options is driven by the effect of ESOs on diluted EPS, with buybacks increasing in the level of in-the-money ESOs outstanding.

Repurchases motivated by EPS considerations have also been linked with benchmark-beating earnings management activity. Controlling for dilution effects, Bens et al. (2003) find that repurchases are increasing in the amount by which earnings undershoot the level required to sustain historical diluted EPS growth. Myers et al. (2007) document similar behavior in a sample of firms characterized by long strings of consecutive quarterly EPS increases, with managers strategically timing repurchases to boost reported EPS when the string would otherwise be broken. Meanwhile, Hribar et al. (2006) conclude that managers use repurchases to meet or beat analysts' consensus EPS forecasts. In all these studies, benchmark-beating stock repurchase activity is motivated through implicit managerial incentives in the form of higher stock-related compensation, greater job security, and a lower cost of capital. ${ }^{2}$

Compensation contracts represent a powerful source of incentives for managers. For example, research demonstrates that executives use their accounting discretion to manipulate earnings in response to compensation-driven considerations (Bushman and Smith 2001). Further, a growing body of evidence suggests that corporate payout decisions are sensitive to executives' compensation arrangements. For instance, firms for which the executives' annual bonus pool is contingent on dividends paid are associated with higher dividend payouts and yields (White 1996), while ESOs that are not dividend-protected create incentives for executives to reduce dividend payments

2 Bens et al. (2003, 75-76) argue that explicit compensation contract considerations are not the source of their findings linking repurchases to EPS manipulation. They estimate firm-specific correlations between CEO cash compensation and reported EPS and use the median correlation to divide firms into high and low cash compensation-EPS sensitivity firms. Tests reveal no evidence that their main results differ across the two subsamples. However, this approach is unlikely to provide a powerful means of distinguishing firms with explicit EPS targets from those using alternative earnings-based performance metrics. Further, since the approach focuses exclusively on cash compensation, it ignores the impact of EPS vesting conditions in long-term compensation. 
(Lambert et al. 1989; Kahle 2002; Fenn and Liang 2001). In related research, Aboody and Kasznik (2008) demonstrate how compensation plan design can help align managers' cash payout decisions with shareholders' tax-driven payout preferences. Finally, Wallace (1997) and Marquardt et al. (2009) examine the link between bonus plan performance conditions and corporate payout policy. Using a sample of firms adopting residual income-based plans (which penalize managers for accumulating capital that earns less than the opportunity cost of capital), Wallace (1997) documents a post-adoption rise in repurchase activity as managers liquidate unproductive assets. Marquardt et al. (2009), meanwhile, provide direct evidence on the link between EPS performance conditions and stock repurchase activity. Specifically, they find that managers are more likely to favor accelerated stock repurchases (which record the full EPS benefits of the repurchase immediately) over regular open market repurchases when their bonus plans are explicitly tied to EPS performance. However, the extent to which EPS-based compensation arrangements explain the propensity to repurchase more generally remains unexplored.

EPS is a popular performance metric used in executive compensation contracts (Murphy 1999; Conyon et al. 2000; Pass et al. 2000). Compensation contracts that tie managerial rewards to EPS create explicit incentives for executives to manage the EPS denominator through repurchases (over and above any implicit market-based incentives associated with increasing stockbased wealth and improving job security). These direct incentives are absent in compensation contracts that employ non-per-share-based earnings metrics such as return on assets, and nonaccounting measures such as stock price or qualitative targets linked to personal objectives. Accordingly, we predict that stock repurchase activity will be positively associated with the incidence of EPS-based performance conditions in executive compensation contracts. We test this prediction in the U.K. where short- and long-term elements of executive pay are linked to EPS (Conyon et al. 2000; Pass et al. 2000; Carter et al. 2009).

\section{Overview of Executive Compensation Arrangements in the U.K.}

The typical compensation package for a U.K. executive director includes both short-term bonus arrangements and longer-term incentives such as options and restricted stock (Conyon and Murphy 2000). Bonus payments are normally linked to short-term performance measures and objectives. In addition, U.K. firms regularly impose performance-vesting conditions in executives' long-term stock- and cash-based plans. Widespread adoption of performance-vesting conditions in executives' long-term compensation plans can be traced to the Greenbury Report (1995), which proposed that all long-term incentives (including option plans) should include challenging performance criteria. After December 31, 1995, revised London Stock Exchange rules required all listed firms to either comply with the Greenbury recommendation or publish a statement explaining noncompliance. Further pressure to adopt performance conditions for long-term incentives was applied by influential shareholder groups including the Association of British Insurers and the National Association of Pension Funds. As a result, performance vesting conditions in long-term plans are now commonplace among U.K. firms (Carter et al. 2009).

While best practice compensation guidelines do not favor any single performance metric, survey evidence reveals widespread adoption of EPS-based targets. For example, Conyon et al. (2000) report that 72 percent of option plans with performance-contingent vesting conditions define targets in terms of EPS growth, while Pass et al. (2000) find that 34 percent of long-term incentive plans (LTIPs) surveyed had an EPS performance condition. Accordingly, the performance conditions applied in long-term compensation arrangements often mirror those used in short-term bonus plans, for which EPS targets have long been used. The widespread use of EPS targets in executive compensation arrangements is expected to create powerful incentives for U.K. executives to manage EPS realizations through repurchases. 


\section{Sample and Data}

\section{DATA AND METHODS}

The initial sampling frame comprises all U.K.-resident firms (excluding closed-end investment trusts) listed on the London Stock Exchange (LSE) with fiscal year-ends between January 1, 1998 and December 31, 2006. The sample period starts in 1998 because executive compensation data are collected with a one-year lag and disclosures relating to performance conditions in executive compensation contracts are patchy before 1997.

Firm-level repurchase data relate to aggregate reacquisitions made during a fiscal year. Only repurchases executed in the open market or via self-tender offer are used in subsequent tests. We hand-collect annual repurchase data from firms' published financial statements. This process involves identifying potential repurchasers using a variety of news sources including the London Stock Exchange Regulatory News Service, the Securities Data Corporation, and The Financial Times. Financial statements with year-ends between January 1998 and December 2006 are then examined for all firms in the provisional list to identify the number, value, and fraction of shares repurchased. The resulting sample comprises 1,047 repurchase firm-year observations for 460 firms. We remove financial firms due to the unique nature of performance measurement in that sector. Utility firms are also removed due to a lack of nonrepurchasing firms in the same sector for matching purposes (see below). A further 67 observations are lost due to missing data required to construct one or more of our test variables. We also exclude ten treasury stock repurchase observations driven entirely by outstanding option commitments. The final sample consists of 665 repurchase firm-years.

Repurchasing firms are drawn from 31 Datastream level-4 nonfinancial industry groups, with no single industry accounting for more than 12 percent of the final sample. The aggregate value of shares reacquired during the sample window exceeds $£ 83$ billion, with an average (median) annual repurchase value of $£ 124.9$ million ( $£ 3.9$ million). Repurchase activity in the U.K. is increasing over time, with the aggregate amount rising from $£ 636$ million in 1998 to almost $£ 28$ billion in 2006. The average (median) annual repurchase involves approximately 5 (3) percent of common shares outstanding. Repurchased shares are cancelled in the majority of cases: only 66 observations (10 percent) utilize the treasury stock option.

Empirical tests require details of performance conditions used in executive compensation contracts, data for which are also hand-collected from firms' published annual reports and financial statements. Collecting such data for all LSE-listed nonrepurchase firms is infeasible. We therefore employ a case-control matched sample design whereby each of the 665 repurchase firm-year observations is paired with a time-, industry- and size-matched nonrepurchasing firm. ${ }^{3}$ Matching by industry (Datastream level-4) helps control for factors that are expected to affect payout policy (Smith and Watts 1992) and compensation arrangements (Antle and Smith 1986), while matching by size (lagged total assets) helps to control for established associations between firm size and repurchase activity (Dittmar 2000; Jagannathan et al. 2000), and between firm size and compensation arrangements (Pass et al. 2000). Nonrepurchase control firms are matched with repurchasers at the fiscal year-end immediately preceding the repurchase year. Nonrepurchasers must not have implemented a buyback at any point prior to the matching year or during the subsequent four-year period.

\footnotetext{
3 Case-control matching unavoidably leads to disproportionate random sampling on the dependent variable. However, subsequent tests linking repurchase activity to EPS-based performance conditions in executive compensation contacts employ logistic regression, a well-known property of which is that slope coefficients remain unbiased in the presence of disproportionate random sampling on the dependent variable (Prentice and Pyke 1979).
} 
Details of the following performance-related elements of executive compensation are collected from repurchase and nonrepurchase firms' annual reports in the matching year: short-term bonus plans, option plans, and long-term incentive plans. Bonus plans comprise all arrangements for which rewards are tied to short-term ( $\leq$ one-year) performance targets. Option plans comprise all stock-based arrangements granting executives the right to acquire shares at a nonzero exercise price. (Firm-wide employee option plans and save-as-you-earn schemes are excluded.) LTIPs consist of all remaining long-term compensation arrangements not classified as options (e.g., deferred bonus schemes, share matching schemes, zero strike price options, stock appreciation rights, long-term cash-based bonus plans, etc.). We record the performance conditions for all active plans in each category. The data-collection process has to confront two disclosure problems. First, a handful of firms fail to unambiguously disclose use of one or more of the three plan types. Second, some firms fail to provide details of the performance conditions used in one or more of their plans. We use previous years' Annual General Meeting resolutions and remuneration disclosures up to two years ahead to verify plan existence and determine performance conditions employed. ${ }^{4}$ Cases for which we cannot unambiguously determine plan existence or the use of an EPS performance condition are coded as nondisclosers.

\section{Research Design}

We expect EPS performance conditions to be more prevalent among repurchasing firms. We test this prediction using a conditional logistic regression to model the probability of a repurchase and a left-censored tobit regression to model the value of repurchases:

$$
\begin{aligned}
& \log \left(\frac{p_{i t}}{1-p_{i t}}\right)=\gamma_{1} \text { NDISC }_{i j t-1}+\gamma_{2} \text { EPS }_{i j t-1}+\sum_{k=1}^{K} \theta_{k} \text { Controls }_{k i t-1}, \\
& \operatorname{Rep}_{i t}=\lambda_{0}+\lambda_{1} \text { NDISC }_{i j t-1}+\lambda_{2} \text { EPS }_{i j t-1}+\sum_{k=1}^{K} \delta_{k} \text { Controls }_{k i t-1}+v_{i t} .
\end{aligned}
$$

For the conditional logistic model presented in Equation (1), $p_{i t}$ is the latent probability that firm $i$ repurchases shares in year $t\left(y_{i t}=1\right)$. The conditional logistic model is the appropriate estimation method for the matched pair structure of our data (Allison 1999, 203). ${ }^{5}$ For the left-censored tobit model presented in Equation (2), Rep is the observed value of the latent propensity to repurchase stock $\left(R e p^{*}\right): R e p_{i t}=0$ if $\operatorname{Rep}_{\text {it }}^{*} \leq 0$ and $R e p_{i t}=$ value of stock repurchases in fiscal year $t$ scaled by lagged total assets if $\operatorname{Rep}_{i t}^{*}>0$.

The vector of explanatory variables is the same in Equations (1) and (2): NDISC is an indicator variable taking the value of 1 if the presence of an EPS performance condition is indeterminate for at least one of the $j$ compensation components $(j=$ bonus plans, stock option plans, and LTIPs), and 0 otherwise; EPS is an indicator variable taking the value of 1 if an EPS performance condition is used in at least one of the $j$ compensation components, and 0 otherwise; and Controls is a vector of $K$ additional factors expected to influence the repurchase decision. ${ }^{6}$ The

4 Compensation disclosures in the U.K. improved dramatically during the late 1990s and early 2000s. When using oneand two-period-ahead remuneration disclosures, we are careful to distinguish between established plans and new plans introduced subsequently.

5 We also estimated Equation (1) using a pooled (unmatched) logistic model with very similar results. Results are available from the authors on request.

6 Incomplete disclosure of performance conditions means that EPS realizations may take one of three forms: EPS condition is used and disclosed; EPS condition is unambiguously not used; and EPS condition is indeterminate due to insufficient disclosure. Defining EPS in Equations (1) and (2) as a three-way categorical variable imposes a linearity constraint on the data. The alternative (unconstrained) approach is to recode the three-way variable as three separate 
set of control variables includes the market-to-book ratio, net leverage, dividend yield, priorperiod abnormal stock price performance, and firm size (Stephens and Weisbach 1998; Dittmar 2000; Grullon and Michaely 2002). Since repurchases have a positive net effect on EPS when a firm's earnings-to-price (E/P) ratio exceeds its opportunity cost of funds, only firms that meet such a condition will repurchase shares to boost EPS. We therefore include an indicator variable for firms reporting negative earnings on the grounds that the $\mathrm{E} / \mathrm{P}$ condition is least likely to hold in such cases. Prior research documents a link between ESO plans and stock repurchases by U.S. firms (Fenn and Liang 2001; Dittmar 2000). Although U.K. regulatory rules governing stock repurchases militate against such behavior during our sample period, for completeness we include the total number of options outstanding for all employees (scaled by market capitalization) as an additional control variable. To ensure that our analysis is capturing effects unique to EPS, we also control for the presence of earnings-based performance conditions of any description. ${ }^{7}$ Finally, we control for the well-established link between repurchases and surplus cash (Stephens and Weisbach 1998; Dittmar 2000; Guay and Harford 2000; Jagannathan et al. 2000). The presence of surplus cash is captured using both stock (surplus cash holdings) and flow (excess cash flow) measures. Our measure of surplus cash holdings is cash and cash equivalents in excess of the level required for normal operations and investments. Following Opler et al. (1999), we estimate surplus cash holdings as the residual from an OLS regression of cash holdings (scaled by lagged noncash assets) on a vector of explanatory variables comprising the market-to-book ratio, net working capital (scaled by lagged total assets), lagged operating cash flow (scaled by lagged total assets), net leverage, R\&D spending (scaled by total revenue), the natural logarithm of market capitalization, an indicator variable for nonzero dividend payments, and industry fixed effects. The regression is estimated annually using all Extel nonfinancial firms with complete data after excluding the top and bottom percentiles of scaled cash holdings. We extract the residuals $\left(\varepsilon_{i t}\right)$ from the annual estimations to construct an indicator variable equal to 1 when $\varepsilon_{i t}>0$, and 0 otherwise.

We use two measures of excess cash flow, one based on operating activities (Free cash flow) and one based on nonoperating activities (Excess investing cash flow). Following Opler and Titman (1993) and Fenn and Liang (2001), Free cash flow is an indicator variable equal to 1 for firms with a market-to-book ratio less than the Extel annual sample median and operating cash flow (scaled by lagged total assets) greater than the Extel annual sample median, and 0 otherwise. Excess investing cash flow is an indicator variable taking the value of 1 when net cash inflow from investing activities is positive, and 0 otherwise. (Investing cash inflows result from the sale of fixed and intangible assets, associates and other investments, and subsidiaries.) All explanatory variables in Equations (1) and (2) are measured at the start of the repurchase year.

\section{Descriptive Statistics}

\section{RESULTS}

Table 1, Panel A reports descriptive statistics for the incidence of bonus plans, option plans, and LTIPs. Frequency counts reported in columns 2-4 reveal most firms operate at least one bonus plan and one option plan, whereas only 40 percent of firms have an active LTIP. Cross-sample comparisons indicate that repurchasers are marginally more likely to operate a bonus plan $(\mathrm{p}=0.09)$. Consistent with the absence of powerful ESO-related motives for stock repurchases in

dummy variables and then use two of these in place of the original variable (Allison 1999, 128-130). Tests reveal that imposing the linearity constraint on our data leads to a reduction in model fit (the change in the likelihood ratio statistic is significant at the 0.01 level), suggesting that the unconstrained formulation presented in Equations (1) and (2) is more appropriate in our case.

7 For example, residual income also creates incentives to distribute capital earning less than the opportunity cost of funds (Wallace 1997). 
TABLE 1

Summary Statistics and Features of Compensation Plan Components for Repurchaser and Nonrepurchaser Matched Pairs

Panel A: Frequency of Plans

\begin{tabular}{|c|c|c|c|c|c|c|c|c|}
\hline \multirow[b]{2}{*}{$\begin{array}{l}\text { Compensation } \\
\text { Component }\end{array}$} & \multicolumn{3}{|c|}{ Plan Status by Firm } & \multicolumn{5}{|c|}{ Number of Plans } \\
\hline & $\geq 1$ Plan & No Plan & $\begin{array}{c}\begin{array}{c}\text { Not } \\
\text { Disclosed }\end{array} \\
\end{array}$ & $\mathbf{n}$ & Mean & Std. Dev. & Median & Max \\
\hline \multicolumn{9}{|l|}{ Bonus Plans } \\
\hline Repurchasers & 601 & 49 & 15 & 605 & 0.931 & 0.277 & 1 & 2 \\
\hline Nonrepurchasers & 596 & 68 & 1 & 600 & 0.904 & 0.315 & 1 & 2 \\
\hline p-value for difference & 0.09 & & & & 0.17 & & 0.17 & \\
\hline \multicolumn{9}{|l|}{ Option Plans } \\
\hline Repurchasers & 591 & 69 & 5 & 759 & 1.150 & 0.621 & 1 & 3 \\
\hline Nonrepurchasers & 601 & 64 & 0 & 789 & 1.186 & 0.620 & 1 & 3 \\
\hline $\mathrm{p}$-value for difference & 0.62 & & & & 0.29 & & 0.31 & \\
\hline \multicolumn{9}{|c|}{ Long-Term Incentive Plans } \\
\hline Repurchasers & 282 & 377 & 6 & 377 & 0.572 & 0.745 & 0 & 3 \\
\hline Nonrepurchasers & 287 & 378 & 0 & 373 & 0.561 & 0.744 & 0 & 3 \\
\hline p-value for difference & 0.89 & & & & 0.77 & & 0.74 & \\
\hline
\end{tabular}

Panel B: Performance Measures by Plan

Performance Measures by

Compensation Component

Bonus Plans

Earnings per share

Profit before tax/EBIT/Operating profit

Residual income

Return on capital

Share price/Total shareholder return

Personal objectives

Other

Not disclosed

Total Number of Plans

Option Plans

Earnings per share

Profit before tax/EBIT/Operating profit

Return on capital

Share price/Total shareholder return

Personal objectives

Other

No performance condition

Not disclosed

Total Number of Plans

Long-Term Incentive Plans

Earnings per share

Profit before tax/EBIT/Operating profit

\section{Frequency Counts}

\begin{tabular}{|c|c|c|c|}
\hline \multicolumn{2}{|c|}{ Repurchasers } & \multicolumn{2}{|c|}{ Nonrepurchasers } \\
\hline n & $\%$ & $\mathbf{n}$ & $\%$ \\
\hline 168 & $(27.8)$ & 121 & $(20.2)$ \\
\hline 303 & $(50.1)$ & 329 & $(54.8)$ \\
\hline 15 & $(2.5)$ & 7 & $(1.2)$ \\
\hline 21 & $(3.5)$ & 34 & $(5.7)$ \\
\hline 16 & (2.6) & 16 & $(2.7)$ \\
\hline 88 & $(14.5)$ & 118 & (19.7) \\
\hline 198 & $(32.7)$ & 252 & $(42.0)$ \\
\hline 153 & $(25.3)$ & 122 & (20.3) \\
\hline 605 & & 600 & \\
\hline 488 & $(64.3)$ & 398 & $(50.4)$ \\
\hline 24 & $(3.2)$ & 15 & (1.9) \\
\hline 4 & $(0.5)$ & 1 & $(0.1)$ \\
\hline 62 & $(8.2)$ & 125 & (15.8) \\
\hline 0 & $(0.0)$ & 1 & $(0.1)$ \\
\hline 8 & $(1.1)$ & 12 & $(1.5)$ \\
\hline 176 & $(23.2)$ & 238 & $(30.2)$ \\
\hline 27 & $(3.6)$ & 9 & $(1.1)$ \\
\hline 759 & & 789 & \\
\hline 155 & (41.1) & 151 & $(40.5)$ \\
\hline 13 & $(3.4)$ & 17 & (4.6) \\
\hline
\end{tabular}

(continued on next page)

The Accounting Review 
Panel B: Performance Measures by Plan

Performance Measures by
Compensation Component

Residual income

Return on capital

Share price/Total shareholder return

Other

No performance condition

Not disclosed

Total Number of Plans
Frequency Counts

\begin{tabular}{|c|c|c|c|}
\hline \multicolumn{2}{|c|}{ Repurchasers } & \multicolumn{2}{|c|}{ Nonrepurchasers } \\
\hline $\mathbf{n}$ & $\%$ & n & $\%$ \\
\hline 6 & (1.6) & 2 & $(0.5)$ \\
\hline 10 & (2.7) & 13 & $(3.5)$ \\
\hline 217 & $(57.6)$ & 196 & $(52.5)$ \\
\hline 14 & $(3.7)$ & 17 & $(4.6)$ \\
\hline 52 & (13.8) & 43 & (11.5) \\
\hline 1 & $(0.3)$ & 3 & $(0.8)$ \\
\hline 377 & & 373 & \\
\hline
\end{tabular}

The sample comprises 665 fiscal years between January 1, 1998 and December 31, 2006 in which firms repurchased shares and 665 nonrepurchase firm-years matched by fiscal year, industry, and lagged total assets.

All compensation data relate to compensation contracts for executive directors. Data are collected on all plans for the following three elements in executives' compensation contracts: bonuses, share options, and long-term incentives. Bonus plans comprise all arrangements where rewards are tied to short-term ( $\leq$ one-year) performance targets. Option plans consist of incentive contracts granting executives the right to acquire their firm's shares a non-zero exercise price. (Firmwide employee share option plans and save-as-you-earn schemes are not included.) Long-term incentive plans (LTIPs) consist of all remaining long-term compensation arrangements not classified as options. Probability values reported in Panel A are for Chi-square tests (column 2), paired t-tests (column 6), and paired Wilcoxon tests (column 8).

For each compensation component, the sum of performance measure percentages reported in Panel B may exceed 100 because some firms use multiple measures in a single plan.

the U.K., the frequency of firms with at least one option plan is equivalent in the two samples, as is the incidence of LTIPs. The final three columns in Panel A report summary statistics for the number of active plans. No significant differences are apparent between the two samples.

Plan-level details of performance conditions are reported in Table 1, Panel B. For bonus plans, 28 percent of the 605 plans operated by repurchasers have EPS performance conditions, as compared to only 20 percent of 600 comparable plans operated by nonrepurchasers. In contrast, aggregate profit-based metrics such as profit before tax, personal objectives, and other measures (e.g., operations metrics, KPIs) are more common among nonrepurchasers. Note also that repurchase firms are characterized by poorer disclosure of bonus-related performance conditions: 25 percent of plans in the repurchase sample contain no details of performance conditions, as compared to only 20 percent of plans in the nonrepurchase sample. Similar patterns are apparent for option plans. Option exercise is conditional on EPS performance in 64 percent of repurchase firms' plans, as compared to 50 percent of plans in the nonrepurchase sample. Results for bonus and option plans provide preliminary evidence that repurchase activity is increasing in the presence of EPS performance conditions. No difference in the use of EPS conditions exists for LTIPs; roughly 40 percent of plans in both samples are conditional on EPS performance.

Summary statistics for our main test variables are reported in Table 2. Seventy-one percent of repurchasers have at least one plan linking at least one element of executive compensation to EPS. The comparable figure for nonrepurchasers is 60 percent, which is significantly lower based on a paired Wilcoxon test $(\mathrm{p}<0.01)$. Analyzing the incidence of EPS targets for each compensation element separately reveals that repurchasers are significantly more likely to have at least one bonus plan and at least one option plan tied to EPS. In contrast, repurchase and nonrepurchase firms are equally likely to have an LTIP conditional on EPS. Significant differences across repur- 


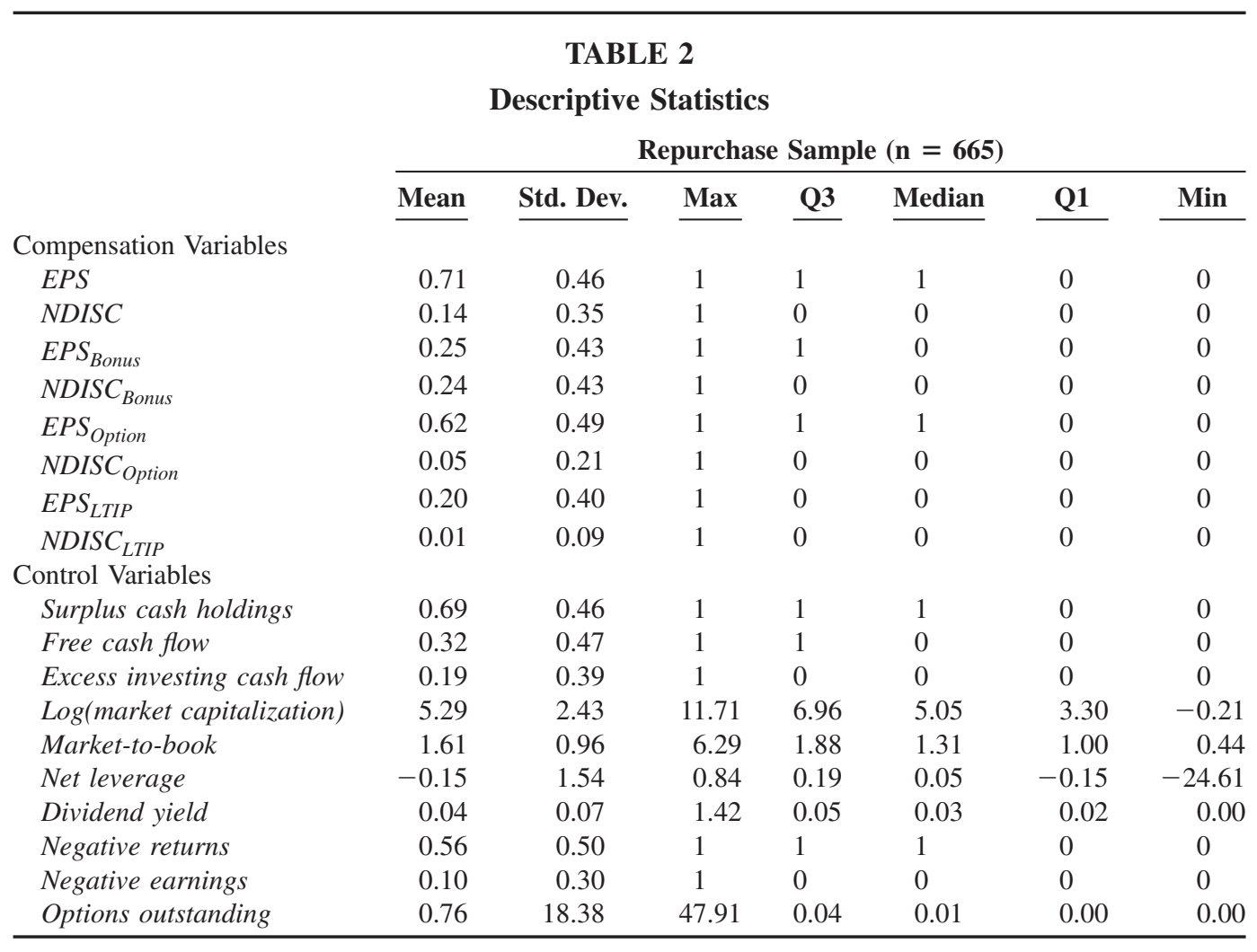

\begin{tabular}{|c|c|c|c|c|c|c|c|c|}
\hline & \multicolumn{7}{|c|}{ Nonrepurchase Sample $(n=665)$} & \multirow{2}{*}{$\begin{array}{l}\text { p-value for } \\
\text { Difference }\end{array}$} \\
\hline & Mean & Std. Dev. & $\operatorname{Max}$ & Q3 & Median & Q1 & Min & \\
\hline \multicolumn{9}{|l|}{ Compensation Variables } \\
\hline$E P S$ & 0.60 & 0.49 & 1 & 1 & 1 & 0 & 0 & 0.01 \\
\hline NDISC & 0.09 & 0.29 & 1 & 0 & 0 & 0 & 0 & 0.01 \\
\hline$E P S_{\text {Bonus }}$ & 0.18 & 0.39 & 1 & 0 & 0 & 0 & 0 & 0.01 \\
\hline$N D I S C_{\text {Bonиs }}$ & 0.18 & 0.38 & 1 & 0 & 0 & 0 & 0 & 0.01 \\
\hline$E P S_{\text {Option }}$ & 0.50 & 0.50 & 1 & 1 & 1 & 0 & 0 & 0.01 \\
\hline$N_{D I S C}$ Option & 0.01 & 0.10 & 1 & 0 & 0 & 0 & 0 & 0.01 \\
\hline$E P S_{L T I P}$ & 0.19 & 0.40 & 1 & 0 & 0 & 0 & 0 & 0.61 \\
\hline$N D I S C_{L T I P}$ & 0.01 & 0.08 & 1 & 0 & 0 & 0 & 0 & 0.75 \\
\hline \multicolumn{9}{|l|}{ Control Variables } \\
\hline Surplus cash holdings & 0.65 & 0.48 & 1 & 1 & 1 & 0 & 0 & 0.09 \\
\hline Free cash flow & 0.29 & 0.45 & 1 & 1 & 0 & 0 & 0 & 0.16 \\
\hline Excess investing cash flow & 0.14 & 0.35 & 1 & 0 & 0 & 0 & 0 & 0.02 \\
\hline Log(market capitalization) & 4.72 & 1.91 & 10.74 & 6.06 & 4.73 & 3.20 & -0.88 & 0.01 \\
\hline Market-to-book & 1.63 & 1.61 & 29.69 & 1.69 & 1.25 & 1.00 & 0.41 & 0.01 \\
\hline Net leverage & 0.03 & 0.88 & 1.87 & 0.29 & 0.15 & -0.02 & -10.69 & 0.01 \\
\hline Dividend yield & 0.03 & 0.09 & 1.46 & 0.04 & 0.02 & 0.00 & 0.00 & 0.01 \\
\hline Negative returns & 0.61 & 0.49 & 1 & 1 & 1 & 0 & 0 & 0.01 \\
\hline Negative earnings & 0.28 & 0.45 & 1 & 1 & 0 & 0 & 0 & 0.01 \\
\hline Options outstanding & 0.16 & 0.77 & 11.24 & 0.07 & 0.02 & 0.01 & 0.00 & 0.01 \\
\hline
\end{tabular}


All variables are measured at the beginning of the repurchase year. The "p-value for Difference" column reports probability values for two-tailed paired Wilcoxon Sign Rank tests of the difference between repurchase and nonrepurchase firms.

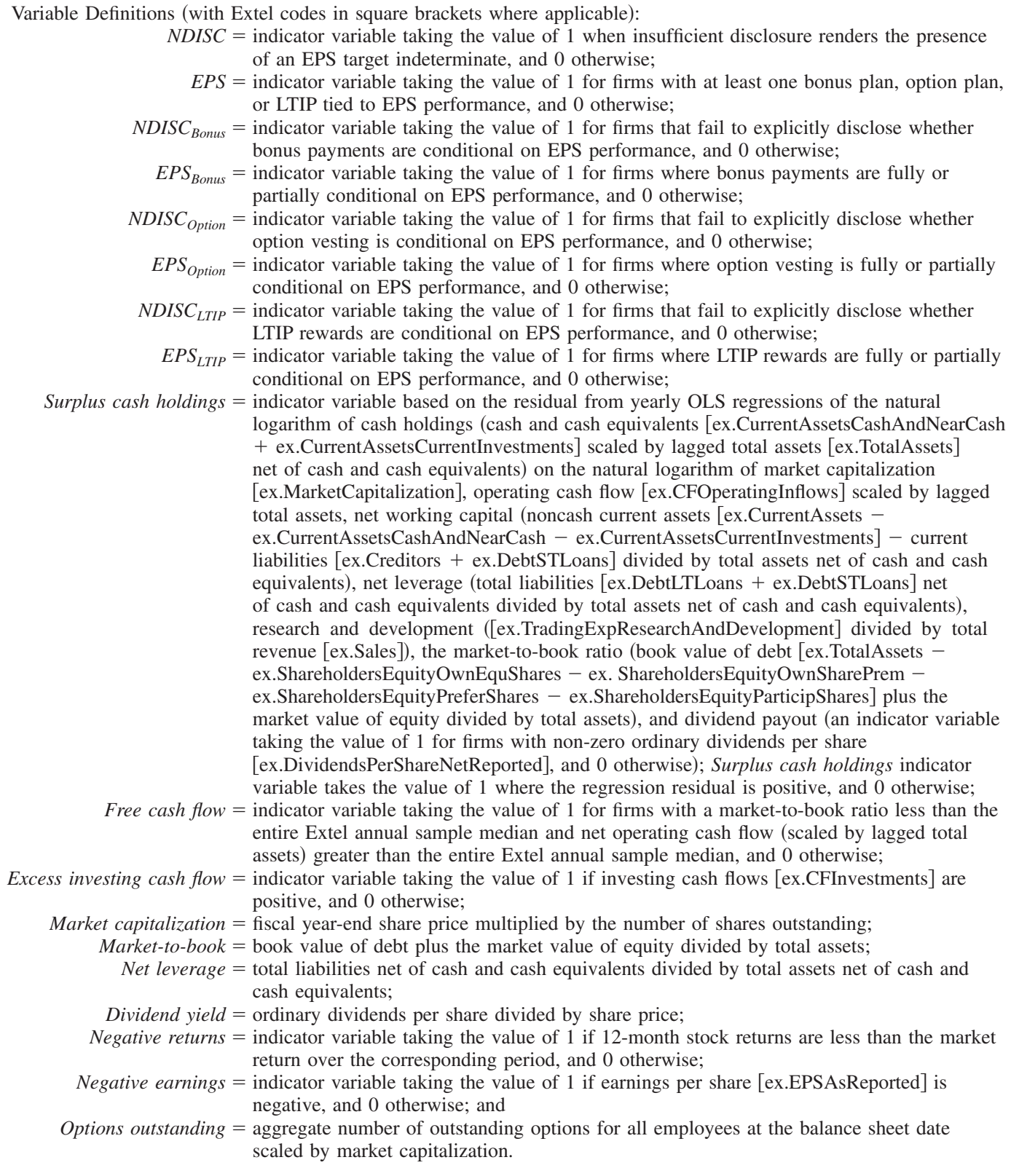

chase and control samples are apparent for almost all control variables. Consistent with prior research, repurchasers have more surplus cash, lower net leverage, and are larger than their nonrepurchaser counterparts. 


\section{Logistic and Tobit Regressions}

Coefficient estimates and model summary statistics for conditional logistic regressions relating the probability of a repurchase to the incidence of EPS-based performance conditions are reported in Table 3, Models 1-3. Results for comparable left-censored tobit regressions are reported in Models 4-5. EPS in Model 1 equals 1 when at least one plan of any type links executive compensation to EPS, and 0 otherwise. As predicted, the estimated coefficient on EPS is positive and significant. EPS performance conditions also represent an economically important driver of repurchase activity; the predicted odds of a repurchase for firms where executive compensation depends on EPS performance are almost twice the odds for firms where payouts are independent of EPS. Note also that the odds ratio for EPS in Model 1 is similar to (and in many cases larger than) the odds ratios associated with traditional determinants of repurchase activity such as excess cash flow and low leverage.

Model 1 also reveals that repurchasers are less likely to disclose details of performance conditions used in executive compensation contracts. The estimated coefficient on NDISC is positive and highly significant, while the odds ratio is large relative to other variables. We have no predictions concerning the link between repurchase activity and the transparency with which firms disclose details of compensation arrangements. To ensure that nondiscloser cases are not confounding the analysis, we re-estimated Model 1 after removing such cases. Results reported in Model 2 are entirely consistent with those in Model 1. Whatever effect NDISC may be capturing, it appears to be distinct from our main prediction.

Of the remaining control variables in Models 1 and 2, coefficient estimates on Free cash flow, Excess investing cash flow, Market-to-book, Net leverage, and Negative earnings are statistically significant and of the predicted sign. In addition, even after controlling for differences in lagged total assets via our matching procedure, repurchasers are characterized by higher market capitalization at the beginning of the repurchase year.

Model 3 in Table 3 provides evidence on the incremental effects of EPS-based bonus, option, and LTIP arrangements. EPS-based bonus and option plans are associated with incremental positive effects of similar magnitude. In contrast, EPS-based LTIPs have no discernable effect on repurchase activity. The absence of an LTIP effect likely reflects the lower incidence of such plans relative to bonus and option plans (see Table 1, Panel A), coupled with the dominance of total shareholder return (TSR) performance conditions in these plans. ${ }^{8}$

Models 4 and 5 in Table 3 are for left-censored tobit regressions modeling the scaled value of repurchases. Findings replicate those for the conditional logistic models. Even after controlling for traditional determinants of repurchases, annual spending on buybacks is positively associated with $E P S$ and the marginal effect for this variable is similar to (and in many cases larger than) the effect for more established drivers of repurchase activity. Consistent with the logistic results, while the coefficient on NDISC is positive and highly significant in Model 4, exclusion of nondisclosing matched pairs (Model 5) does not affect the EPS coefficient estimate. Collectively, results reported

8 Although many firms employ EPS targets in their LTIPs, these are often combined with (and subordinate to) a TSR condition. For example, awards under KBC Advanced Technologies' share-based LTIP require minimum TSR over a three-year period equal to the median for the FTSE Small Cap Index over the same period, with maximum awards for TSR at or above 75th percentile ranking. Irrespective of TSR performance, awards are conditional on real EPS growth over the performance period (KBC Advanced Technologies plc Annual Report 2002, 15-16). 
TABLE 3

Coefficient Estimates and Model Summary Statistics for Conditional Logistic (Left-Censored Tobit) Regressions Relating the Probability (Scaled Value) of a Repurchase to the Incidence of EPS-Based Performance Conditions in Executive Compensation Contracts

\begin{tabular}{|c|c|c|c|c|c|c|}
\hline \multirow[b]{2}{*}{ Variables } & \multirow{2}{*}{$\begin{array}{l}\text { Predicted } \\
\text { Sign }\end{array}$} & \multicolumn{3}{|c|}{ Logistic Models } & \multicolumn{2}{|c|}{ Tobit Models } \\
\hline & & Model 1 & Model 2 & Model 3 & Model 4 & Model 5 \\
\hline \multirow[t]{3}{*}{ Surplus cash holdings } & $(+)$ & 0.20 & 0.24 & 0.24 & 0.01 & 0.02 \\
\hline & & 1.22 & 1.27 & 1.27 & 0.00 & 0.00 \\
\hline & & $(0.18)$ & $(0.17)$ & $(0.12)$ & $(0.01)$ & $(0.02)$ \\
\hline \multirow[t]{3}{*}{ Free cash flow } & $(+)$ & 0.69 & 0.60 & 0.66 & 0.00 & 0.00 \\
\hline & & 2.00 & 1.83 & 1.93 & 0.00 & 0.00 \\
\hline & & $(0.01)$ & $(0.01)$ & $(0.01)$ & $(0.61)$ & $(0.77)$ \\
\hline \multirow[t]{3}{*}{ Excess investing cash flow } & $(+)$ & 0.71 & 0.86 & 0.75 & 0.02 & 0.03 \\
\hline & & 2.03 & 2.40 & 2.11 & 0.01 & 0.01 \\
\hline & & $(0.01)$ & $(0.01)$ & $(0.01)$ & $(0.01)$ & $(0.01)$ \\
\hline \multirow[t]{3}{*}{ Log(market capitalization) } & $(?)$ & 1.27 & 1.51 & 1.22 & 0.00 & 0.00 \\
\hline & & 3.56 & 4.52 & 3.39 & 0.00 & 0.00 \\
\hline & & $(0.01)$ & $(0.01)$ & $(0.01)$ & $(0.01)$ & $(0.01)$ \\
\hline \multirow[t]{3}{*}{ Market-to-book } & $(-)$ & -0.72 & -0.81 & -0.68 & 0.01 & 0.01 \\
\hline & & 0.49 & 0.45 & 0.51 & 0.00 & 0.00 \\
\hline & & $(0.01)$ & $(0.01)$ & $(0.01)$ & $(0.01)$ & $(0.01)$ \\
\hline \multirow[t]{3}{*}{ Net leverage } & $(-)$ & -0.43 & -0.46 & -0.43 & -0.01 & -0.01 \\
\hline & & 0.65 & 0.63 & 0.65 & -0.00 & -0.00 \\
\hline & & $(0.01)$ & $(0.01)$ & $(0.01)$ & $(0.01)$ & $(0.01)$ \\
\hline \multirow[t]{3}{*}{ Dividend yield } & $(?)$ & 1.18 & 1.34 & 1.15 & 0.01 & 0.00 \\
\hline & & 3.25 & 3.82 & 3.15 & 0.00 & 0.00 \\
\hline & & $(0.20)$ & $(0.17)$ & $(0.23)$ & $(0.80)$ & $(0.93)$ \\
\hline \multirow[t]{3}{*}{ Negative returns } & $(+)$ & -0.05 & -0.06 & -0.03 & 0.00 & 0.00 \\
\hline & & 0.95 & 0.94 & 0.97 & 0.00 & 0.00 \\
\hline & & $(0.73)$ & $(0.73)$ & $(0.84)$ & $(0.99)$ & $(0.98)$ \\
\hline \multirow[t]{3}{*}{ Negative earnings } & $(-)$ & -1.22 & -1.38 & -1.14 & -0.05 & -0.06 \\
\hline & & 0.30 & 0.25 & 0.32 & -0.01 & -0.01 \\
\hline & & $(0.01)$ & $(0.01)$ & $(0.01)$ & $(0.01)$ & $(0.01)$ \\
\hline \multirow[t]{3}{*}{ Options outstanding } & $(+)$ & -0.021 & -0.03 & -0.02 & -0.00 & -0.00 \\
\hline & & 0.98 & 0.98 & 0.98 & -0.00 & -0.00 \\
\hline & & $(0.10)$ & $(0.13)$ & $(0.13)$ & $(0.04)$ & $(0.07)$ \\
\hline \multirow[t]{3}{*}{ Earnings-based target } & $(?)$ & -0.15 & -0.22 & -0.06 & -0.01 & -0.01 \\
\hline & & 0.86 & 0.80 & 0.94 & -0.00 & -0.00 \\
\hline & & $(0.33)$ & $(0.21)$ & $(0.74)$ & $(0.28)$ & $(0.34)$ \\
\hline \multirow[t]{3}{*}{ NDISC } & $(?)$ & 1.29 & & & 0.04 & \\
\hline & & 3.62 & & & 0.01 & \\
\hline & & $(0.01)$ & & & $(0.01)$ & \\
\hline \multirow[t]{3}{*}{ EPS } & $(+)$ & 0.65 & 0.71 & & 0.03 & 0.03 \\
\hline & & 1.91 & 2.03 & & 0.01 & 0.01 \\
\hline & & $(0.01)$ & $(0.01)$ & & $(0.01)$ & $(0.01)$ \\
\hline \multirow[t]{2}{*}{$N D I S C_{\text {Bonus }}$} & $(?)$ & & & 0.54 & & \\
\hline & & & & $\begin{array}{l}1.72 \\
(0.02)\end{array}$ & & \\
\hline
\end{tabular}


TABLE 3 (continued)

\begin{tabular}{|c|c|c|c|c|c|c|}
\hline \multirow[b]{2}{*}{ Variables } & \multirow{2}{*}{$\begin{array}{c}\text { Predicted } \\
\text { Sign } \\
\end{array}$} & \multicolumn{3}{|c|}{ Logistic Models } & \multicolumn{2}{|c|}{ Tobit Models } \\
\hline & & Model 1 & Model 2 & Model 3 & Model 4 & Model 5 \\
\hline \multirow[t]{3}{*}{$E_{P} S_{\text {Bопиs }}$} & $(+)$ & & & 0.36 & & \\
\hline & & & & 1.43 & & \\
\hline & & & & $(0.07)$ & & \\
\hline \multirow[t]{3}{*}{$N D I S C_{\text {Option }}$} & $(?)$ & & & 1.95 & & \\
\hline & & & & 7.03 & & \\
\hline & & & & $(0.01)$ & & \\
\hline \multirow[t]{3}{*}{$E P S_{\text {Option }}$} & $(+)$ & & & 0.38 & & \\
\hline & & & & 1.46 & & \\
\hline & & & & $(0.02)$ & & \\
\hline \multirow[t]{3}{*}{$N D I S C_{L T I P}$} & $(?)$ & & & -0.80 & & \\
\hline & & & & 0.45 & & \\
\hline & & & & $(0.38)$ & & \\
\hline \multirow[t]{3}{*}{$E P S_{L T I P}$} & $(+)$ & & & -0.08 & & \\
\hline & & & & 0.92 & & \\
\hline & & & & $(0.67)$ & & \\
\hline Intercept & $(?)$ & & & & $\begin{array}{c}-0.08 \\
(0.01)\end{array}$ & $\begin{array}{r}-0.08 \\
(0.01)\end{array}$ \\
\hline Likelihood ratio & & 278.44 & 233.59 & 283.14 & 328.63 & 276.65 \\
\hline p-value & & 0.01 & 0.01 & 0.01 & & \\
\hline Pseudo $\mathrm{R}^{2}$ & & 0.46 & 0.48 & 0.46 & & \\
\hline$\%$ classified correctly & & 77.30 & 77.70 & 75.60 & & \\
\hline $\mathrm{n}$ & & 665 & 524 & 665 & 1330 & 1173 \\
\hline n censored & & & & & 665 & 602 \\
\hline
\end{tabular}

Three values are reported for each covariate: the first value is the coefficient estimate; the second (italicized) value is the odds ratio (marginal effect) for logistic (tobit) models; and the third value (in parentheses) is the two-tailed probability value.

The dependent variable in the columns headed "Logistic Models" is the logarithm of the odds of a repurchase. The dependent variable in the columns headed "Tobit Models" is the aggregate amount (including expenses) spent repurchasing shares during fiscal year $t$, scaled by lagged total assets. All variables are measured at the beginning of the repurchase year. Marginal effects for the tobit models are equal to the probability of a no-limit observation multiplied by the coefficient estimate and are evaluated at the mean of each covariate.

Variable Definitions:

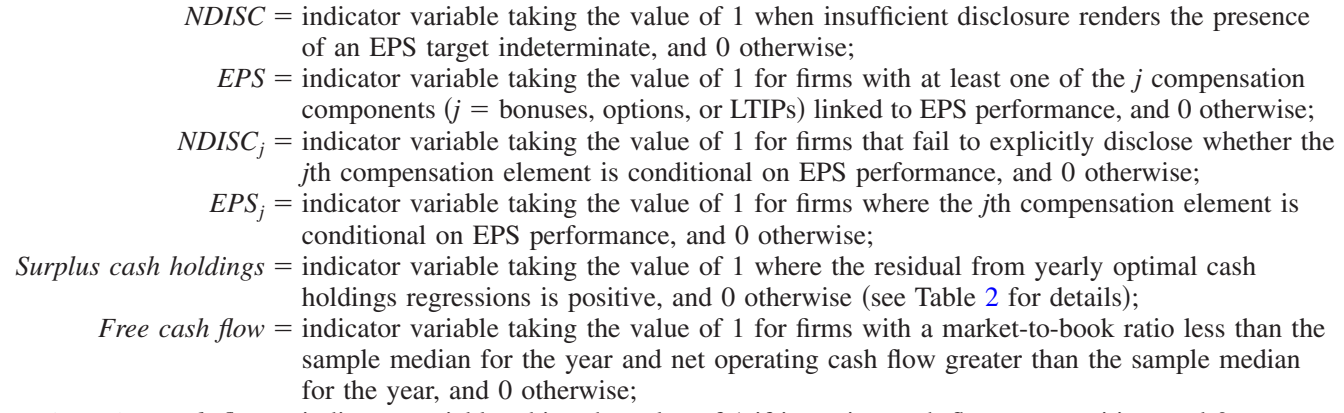

Excess investing cash flow $=$ indicator variable taking the value of 1 if investing cash flows are positive, and 0 otherwise;

(continued on next page) 


\section{TABLE 3 (continued)}

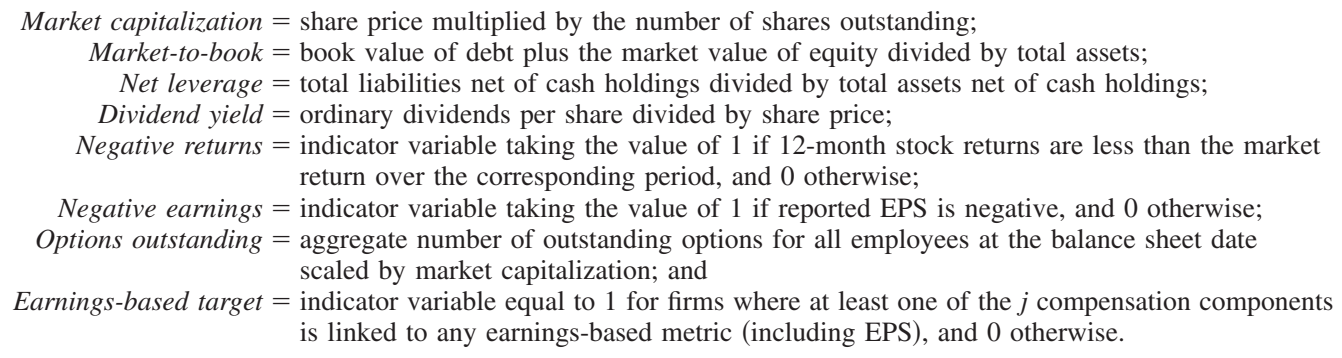

in Table 3 provide consistent evidence that EPS-based performance conditions in executive compensation contracts are an important determinant of repurchase activity among U.K. firms. ${ }^{9}$

\section{FURTHER ANALYSIS}

While tests presented in the previous section establish an association between repurchase activity and performance conditions applied in executive compensation contracts, they leave unresolved the more fundamental question of whether such a link is in shareholders' best interests. This section seeks evidence on the costs and benefits associated with compensation-driven repurchase activity. We begin by testing whether repurchasers with EPS targets exhibit weaker performance (lower payouts to shareholders) as a consequence of management diverting funds from profitable investment opportunities (regular dividends) to fund repurchase activity. Next, we test whether compensation-driven repurchases help to alleviate the problems of surplus cash, suboptimally low leverage, market mispricing, and accrual manipulation.

\section{Post-Repurchase Performance and Payouts}

Bens et al. (2002) conclude that U.S. managers divert capital from positive NPV investments to fund repurchases aimed at offsetting the dilutive impact of ESOs. If managers adopt the same strategy to achieve EPS performance targets, then EPS-induced repurchases could represent a serious cost for shareholders in the form of underinvestment. Accordingly, we examine whether a higher probability of repurchases in the presence of EPS-based compensation arrangements is associated with material underinvestment problems.

All else equal, failure to exploit profitable investment opportunities by channeling capital from positive NPV projects to fund repurchases should be reflected in inferior future performance. Tests reported in Table 4 compare the performance of repurchasers and nonrepurchasers using a difference-in-differences OLS specification in which the dependent variable is the change in performance from the pre- to the post-repurchase period. We estimate models for two alternative performance metrics: change in return on assets $(\triangle R O A)$ and change in market-adjusted stock returns $(\Delta$ Returns $)$. The vector of explanatory variables includes indicator variables for repurchas-

9 In supplementary tests we explored whether the propensity for repurchases is increasing in the number of compensation elements linked explicitly to EPS. The indicator variable $E P S_{\text {Single }}\left(E P S_{M u l t i}\right)$ captures firm-years where one (more than one) compensation element is tied to EPS. For conditional logistic regressions, coefficient estimates on $E P S_{\text {Single }}$ and $E P S_{M u l t i}$ are 0.60 and 0.79 , respectively, and significant at the $\mathrm{p}<0.01$ level. For tobit regressions, coefficient estimates on both covariates are equal to 0.03 and statistically significant at the $p<0.01$ level. Results indicate that repurchases are more likely for firms with single and multiple components of pay tied to EPS. However, tests fail to reject equality of coefficient estimates in favor of the alternative hypothesis that the coefficient on $E P S_{\text {Multi }}>E P S_{\text {Single }}$. 


\section{TABLE 4}

Coefficient Estimates and Model Summary Statistics for Difference-in-Differences OLS Regressions of Change in Performance Relative to Repurchase Year $t$

\begin{tabular}{|c|c|c|c|c|c|c|}
\hline \multirow[b]{3}{*}{ Variable } & \multicolumn{4}{|c|}{$\Delta$ Performance: Pre- to Post-Repurchase } & \multirow{2}{*}{\multicolumn{2}{|c|}{$\begin{array}{c}\text { DPerformance } \\
(t-1 \text { to } t+1) \text { for: }\end{array}$}} \\
\hline & \multicolumn{2}{|c|}{$\triangle R O A$} & \multicolumn{2}{|c|}{$\Delta$ Returns } & & \\
\hline & $t-1$ to $t+1$ & $t-1$ to $t+2$ & $t-1$ to $t+1$ & $t-1$ to $t+2$ & $\Delta R O A$ & DReturns \\
\hline$R O A$ & $\begin{array}{c}-0.32 \\
(0.01)\end{array}$ & $\begin{array}{r}-0.29 \\
(0.01)\end{array}$ & $\begin{array}{r}-0.17 \\
(0.04)\end{array}$ & $\begin{array}{r}-0.04 \\
(0.63)\end{array}$ & $\begin{array}{c}-0.32 \\
(0.01)\end{array}$ & $\begin{array}{c}-0.17 \\
(0.05)\end{array}$ \\
\hline Negative earnings & $\begin{array}{c}-0.02 \\
(0.06)\end{array}$ & $\begin{array}{c}-0.01 \\
(0.50)\end{array}$ & $\begin{array}{c}0.05 \\
(0.23)\end{array}$ & $\begin{array}{c}-0.03 \\
(0.45)\end{array}$ & $\begin{array}{c}-0.02 \\
(0.05)\end{array}$ & $\begin{array}{c}0.04 \\
(0.31)\end{array}$ \\
\hline Returns & $\begin{array}{c}0.01 \\
(0.15)\end{array}$ & $\begin{array}{c}0.01 \\
(0.09)\end{array}$ & $\begin{array}{c}-0.90 \\
(0.01)\end{array}$ & $\begin{array}{c}-0.94 \\
(0.01)\end{array}$ & $\begin{array}{c}0.01 \\
(0.14)\end{array}$ & $\begin{array}{c}-0.90 \\
(0.01)\end{array}$ \\
\hline $\log ($ Total assets $)$ & $\begin{array}{c}0.01 \\
(0.01)\end{array}$ & $\begin{array}{c}0.01 \\
(0.01)\end{array}$ & $\begin{array}{c}0.01 \\
(0.37)\end{array}$ & $\begin{array}{c}-0.01 \\
(0.47)\end{array}$ & $\begin{array}{c}0.01 \\
(0.01)\end{array}$ & $\begin{array}{c}0.01 \\
(0.17)\end{array}$ \\
\hline$\Delta \log ($ Total assets $)$ & $\begin{array}{c}0.04 \\
(0.01)\end{array}$ & $\begin{array}{c}0.04 \\
(0.01)\end{array}$ & $\begin{array}{c}0.20 \\
(0.01)\end{array}$ & $\begin{array}{c}0.15 \\
(0.01)\end{array}$ & $\begin{array}{c}0.04 \\
(0.01)\end{array}$ & $\begin{array}{c}0.19 \\
(0.01)\end{array}$ \\
\hline Market-to-book & $\begin{array}{r}-0.01 \\
(0.02)\end{array}$ & $\begin{array}{r}-0.01 \\
(0.01)\end{array}$ & $\begin{array}{r}-0.04 \\
(0.01)\end{array}$ & $\begin{array}{r}-0.02 \\
(0.13)\end{array}$ & $\begin{array}{r}-0.01 \\
(0.01)\end{array}$ & $\begin{array}{r}-0.04 \\
(0.01)\end{array}$ \\
\hline Leverage & $\begin{array}{c}-0.01 \\
(0.78)\end{array}$ & $\begin{array}{c}-0.04 \\
(0.14)\end{array}$ & $\begin{array}{c}-0.11 \\
(0.19)\end{array}$ & $\begin{array}{c}-0.04 \\
(0.71)\end{array}$ & $\begin{array}{c}-0.01 \\
(0.78)\end{array}$ & $\begin{array}{c}-0.13 \\
(0.14)\end{array}$ \\
\hline Working capital & $\begin{array}{c}0.00 \\
(0.79)\end{array}$ & $\begin{array}{c}0.01 \\
(0.86)\end{array}$ & $\begin{array}{c}-0.01 \\
(0.01)\end{array}$ & $\begin{array}{c}-0.01 \\
(0.01)\end{array}$ & $\begin{array}{c}0.00 \\
(0.75)\end{array}$ & $\begin{array}{c}-0.01 \\
(0.01)\end{array}$ \\
\hline Investing cash flow & $\begin{array}{c}0.02 \\
(0.43)\end{array}$ & $\begin{array}{c}0.00 \\
(0.92)\end{array}$ & $\begin{array}{r}-0.02 \\
(0.90)\end{array}$ & $\begin{array}{r}-0.02 \\
(0.88)\end{array}$ & $\begin{array}{c}0.03 \\
(0.38)\end{array}$ & $\begin{array}{c}0.09 \\
(0.48)\end{array}$ \\
\hline Operating cash flow & $\begin{array}{c}0.11 \\
(0.01)\end{array}$ & $\begin{array}{c}0.03 \\
(0.48)\end{array}$ & $\begin{array}{r}-0.02 \\
(0.87)\end{array}$ & $\begin{array}{c}-0.01 \\
(0.94)\end{array}$ & $\begin{array}{c}0.11 \\
(0.01)\end{array}$ & $\begin{array}{c}0.05 \\
(0.75)\end{array}$ \\
\hline Cash holdings & $\begin{array}{c}-0.03 \\
(0.35)\end{array}$ & $\begin{array}{c}-0.06 \\
(0.07)\end{array}$ & $\begin{array}{c}0.02 \\
(0.88)\end{array}$ & $\begin{array}{c}-0.24 \\
(0.06)\end{array}$ & $\begin{array}{c}-0.03 \\
(0.39)\end{array}$ & $\begin{array}{c}0.04 \\
(0.73)\end{array}$ \\
\hline Options outstanding & $\begin{array}{r}-0.00 \\
(0.39)\end{array}$ & $\begin{array}{r}-0.00 \\
(0.42)\end{array}$ & $\begin{array}{c}-0.01 \\
(0.01)\end{array}$ & $\begin{array}{c}0.01 \\
(0.94)\end{array}$ & $\begin{array}{c}0.01 \\
(0.61)\end{array}$ & $\begin{array}{c}-0.01 \\
(0.01)\end{array}$ \\
\hline Repurchase & $\begin{array}{c}-0.01 \\
(0.37)\end{array}$ & $\begin{array}{c}-0.01 \\
(0.66)\end{array}$ & $\begin{array}{c}0.11 \\
(0.04)\end{array}$ & $\begin{array}{c}0.09 \\
(0.10)\end{array}$ & & \\
\hline EPS & $\begin{array}{c}0.01 \\
(0.23)\end{array}$ & $\begin{array}{c}0.00 \\
(0.86)\end{array}$ & $\begin{array}{c}0.08 \\
(0.06)\end{array}$ & $\begin{array}{c}0.00 \\
(0.97)\end{array}$ & & \\
\hline Repurchase $\times$ EPS & $\begin{array}{c}0.02 \\
(0.29)\end{array}$ & $\begin{array}{c}0.01 \\
(0.43)\end{array}$ & $\begin{array}{r}-0.09 \\
(0.14)\end{array}$ & $\begin{array}{r}-0.04 \\
(0.56)\end{array}$ & & \\
\hline Repurchase $_{\text {Cash rich }}$ & & & & & $\begin{array}{r}-0.04 \\
(0.16)\end{array}$ & $\begin{array}{r}-0.12 \\
(0.29)\end{array}$ \\
\hline Repurchase $_{\text {Cash constrained }}$ & & & & & $\begin{array}{r}-0.02 \\
(0.14)\end{array}$ & $\begin{array}{c}0.13 \\
(0.03)\end{array}$ \\
\hline Nonrepurchase $_{\text {Cash rich }}$ & & & & & $\begin{array}{r}-0.01 \\
(0.49)\end{array}$ & $\begin{array}{r}-0.01 \\
(0.86)\end{array}$ \\
\hline Repurchase $_{\text {Cash rich }} \times$ EPS & & & & & $\begin{array}{c}0.05 \\
(0.09)\end{array}$ & $\begin{array}{c}0.07 \\
(0.54)\end{array}$ \\
\hline 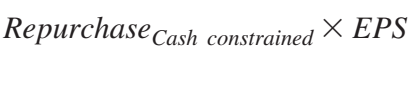 & & & & & $\begin{array}{c}0.03 \\
(0.03)\end{array}$ & $\begin{array}{r}-0.10 \\
(0.12)\end{array}$ \\
\hline Nonrepurchase $_{\text {Cash rich }} \times E P S$ & & & & & $\begin{array}{c}0.00 \\
(0.83)\end{array}$ & $\begin{array}{c}0.02 \\
(0.71)\end{array}$ \\
\hline
\end{tabular}


TABLE 4 (continued)

\begin{tabular}{|c|c|c|c|c|c|c|}
\hline \multirow[b]{3}{*}{ Variable } & \multicolumn{4}{|c|}{ DPerformance: Pre- to Post-Repurchase } & \multirow{2}{*}{\multicolumn{2}{|c|}{$\begin{array}{c}\text { DPerformance } \\
(t-1 \text { to } t+1) \text { for: }\end{array}$}} \\
\hline & \multicolumn{2}{|c|}{$\triangle R O A$} & \multicolumn{2}{|c|}{ DReturns } & & \\
\hline & $t-1$ to $t+1$ & $t-1$ to $t+2$ & $t-1$ to $t+1$ & $t-1$ to $t+2$ & $\triangle R O A$ & $\Delta$ Returns \\
\hline Intercept & $\begin{array}{c}-0.04 \\
(0.06)\end{array}$ & $\begin{array}{c}-0.02 \\
(0.50)\end{array}$ & $\begin{array}{c}0.03 \\
(0.73)\end{array}$ & $\begin{array}{c}0.10 \\
(0.24)\end{array}$ & $\begin{array}{c}-0.03 \\
(0.17)\end{array}$ & $\begin{array}{c}0.09 \\
(0.32)\end{array}$ \\
\hline Industry effects & Yes & Yes & Yes & Yes & Yes & Yes \\
\hline Year effects & Yes & Yes & Yes & Yes & Yes & Yes \\
\hline Adjusted $\mathrm{R}^{2}$ & 0.21 & 0.20 & 0.51 & 0.55 & 0.20 & 0.51 \\
\hline p-value & 0.01 & 0.01 & 0.01 & 0.01 & 0.01 & 0.01 \\
\hline $\mathrm{n}$ & 1178 & 930 & 1176 & 930 & 1178 & 1176 \\
\hline
\end{tabular}

Performance is measured using return on assets $(R O A)$ and 12-month market-adjusted stock returns (Returns). Two-tailed probability values are reported in parentheses. All explanatory variables are measured at the beginning of the repurchase year unless otherwise indicated.

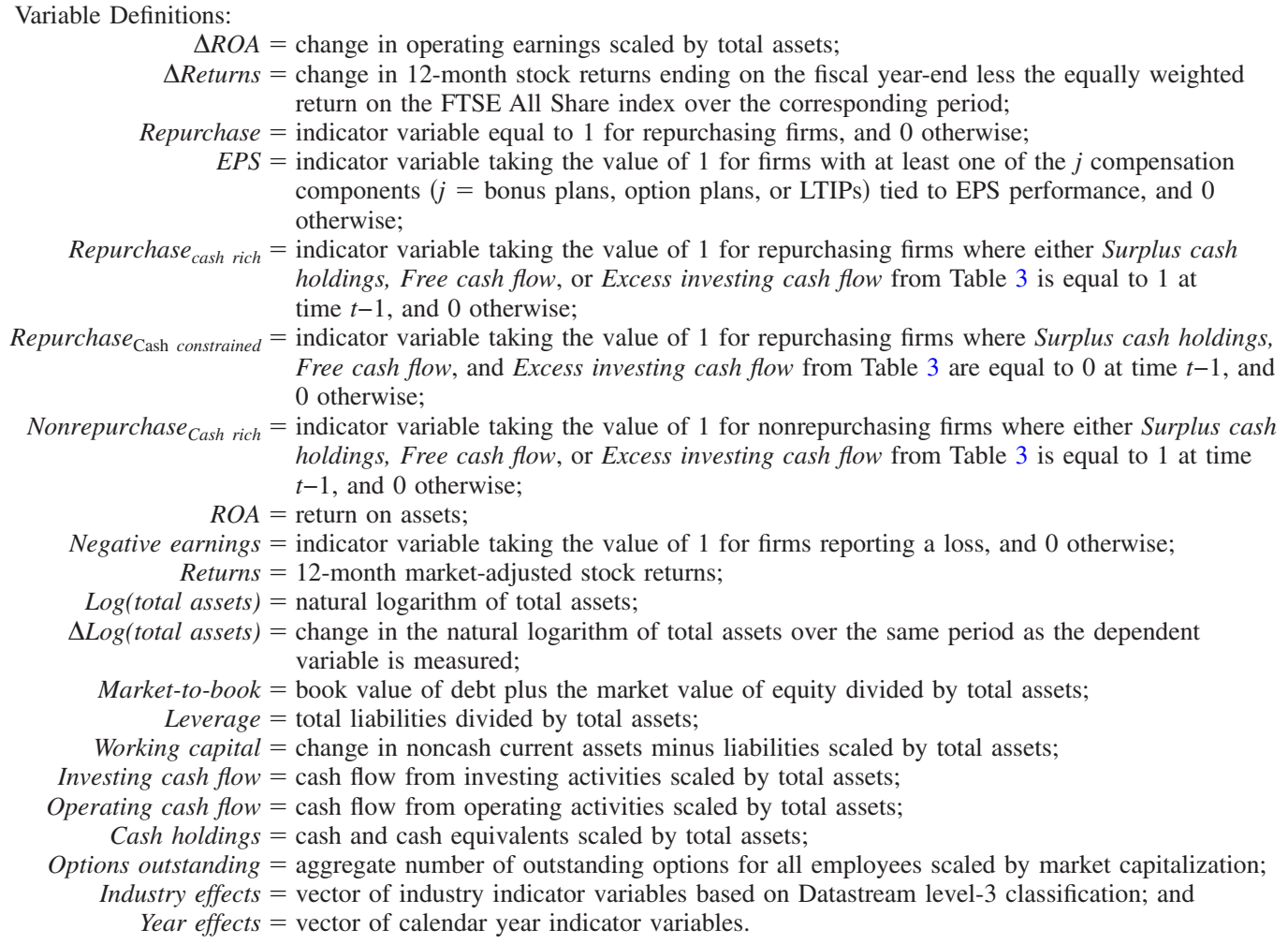

ers and firms with EPS-based performance conditions, respectively, the associated two-way interaction effect, and a set of controls. Columns 2 and 3 (4 and 5) in Table 4 report results for $\triangle R O A$ $(\triangle$ Returns). Findings provide no evidence that repurchasers in general, or repurchases with EPS conditions in particular, exhibit inferior post-repurchase performance. Estimated coefficients on the Repurchase indicator variable are either insignificant in the $\triangle R O A$ models or positive in the 
$\triangle$ Returns models, while coefficient estimates on Repurchase $\times E P S$ are consistently insignificant. Our findings do not support the view that EPS-based performance targets encourage management to divert cash from positive NPV projects to fund buybacks.

The incentive to channel funds away from profitable investments to support repurchases may be especially strong among the subset of firms with limited cash resources. Columns 6 and 7 in Table 4 extend the previous analysis by replacing Repurchase with the following three indicator variables to capture firms' pre-repurchase cash characteristics: Repurchase $_{\text {Cash rich }}$ takes the value of 1 for repurchasing firms where either Surplus cash holdings, Free cash flow, or Excess investing cash flow from Table 3 equals 1 at time $t-1$, and 0 otherwise; Repurchase Cash constrained $_{\text {takes }}$ the value of 1 for repurchasing firms where Surplus cash holdings, Free cash flow, and Excess investing cash flow equal 0 at time $t-1$, and 0 otherwise; and Nonrepurchase Cash rich $_{\text {, }}$ takes the value of 1 for nonrepurchasing firms where either Surplus cash holdings, Free cash flow, or Excess investing cash flow equals 1 at time $t-1$, and 0 otherwise. All three indicators are also interacted with EPS to capture incremental effects associated with EPS-based compensation. Absent EPS targets, cash-constrained repurchasers are associated with similar accounting performance (column 6) and superior market performance (column 7) in the post-repurchase period relative to other groups. Coefficient estimates on the Repurchase Cash constrained $\times E P S$ interaction are either positive $(\triangle R O A$ model) or indistinguishable from 0 ( $\triangle$ Return model). Collectively, these findings provide no evidence that cash-constrained repurchasers, as a group, are characterized by abnormally weak future performance, or that the subset of cash-constrained repurchasers with EPS conditions exhibit incrementally worse performance.

Profitable investment opportunities are not the only source of funds for repurchases that could impose costs on shareholders. A second potentially costly source is regular dividend payments. Because dividends are sticky and dividend cuts are associated with significant stock price declines, regular dividend payments represent a permanent commitment to distribute cash flows and, as such, serve as a disciplinary force on managers' actions (Easterbrook 1984). Repurchases, by comparison, do not imply the same ongoing commitment and are therefore more suited to distributing transitory cash flow shocks (Guay and Harford 2000; Jagannathan et al. 2000). Using cash flows underpinning dividends to fund repurchases could therefore weaken monitoring through a lower commitment to ongoing payouts. Alternatively, repurchases may be associated with increased payouts to shareholders if they enable managers to disgorge lumpy cash surpluses in a timely fashion alongside regular dividend payments.

We examine the impact of EPS-motivated repurchases on payouts to shareholders in two ways. First, we model the annual change in total payouts (dividends plus repurchases scaled by lagged total assets) in the repurchase year using a difference-in-differences tobit regression. Explanatory variables include indicator variables for repurchasers and firms with EPS-based performance conditions, the associated two-way interaction effect, and a vector of controls. Column 2 in Table 5 presents results estimated using the full sample. The Repurchase coefficient estimate is positive and significant, indicating that repurchasers experience higher payout increases in the repurchase year. The estimated coefficient on Repurchase $\times E P S$ is not significant at conventional levels; payout increases for repurchases with EPS-contingent compensation are indistinguishable from those exhibited by non-EPS repurchasers. These results do not support dividend substitution claims for repurchasers in general and EPS-contingent repurchasers in particular. Instead, findings suggest that dividends and repurchases represent complementary payout options that in conjunction yield higher payouts to shareholders regardless of whether repurchases are driven by EPScontingent compensation arrangements.

Columns 3 and 4 in Table 5 examine change in total payouts for firms with and without surplus cash at time $t-1$, respectively. Results and conclusions are similar to those reported for the full sample in column 2. While results in column 3 provide little evidence that EPS targets are 
TABLE 5

Coefficient Estimates and Model Summary Statistics for Pooled Regressions Relating Payout Policy to Repurchase Activity and the Incidence of EPS-Based Performance Conditions in Executive Compensation Contracts

\begin{tabular}{|c|c|c|c|c|}
\hline \multirow[b]{2}{*}{ Variable } & \multicolumn{3}{|c|}{ Tobit Models: $\Delta$ Total Payout } & \multirow{2}{*}{$\begin{array}{c}\text { OLS Mode } \\
\begin{array}{c}\text { Dividend } \\
\text { Forecast } \\
\text { Error }\end{array}\end{array}$} \\
\hline & Full Sample & $\begin{array}{c}\text { Surplus } \\
\text { Cash: } \\
\text { Yes }\end{array}$ & $\begin{array}{c}\text { Surplus } \\
\text { Cash: } \\
\text { No }\end{array}$ & \\
\hline Surplus cash holdings & $\begin{array}{c}0.01 \\
(0.06)\end{array}$ & & & $\begin{array}{c}0.03 \\
(0.24)\end{array}$ \\
\hline Free cash flow & $\begin{array}{c}-0.01 \\
(0.10)\end{array}$ & & & $\begin{array}{c}0.06 \\
(0.02)\end{array}$ \\
\hline Excess investing cash flow & $\begin{array}{c}-0.01 \\
(0.05)\end{array}$ & & & $\begin{array}{c}-0.06 \\
(0.04)\end{array}$ \\
\hline Log(Market capitalization) & $\begin{array}{c}0.00 \\
(0.09)\end{array}$ & $\begin{array}{c}0.00 \\
(0.19)\end{array}$ & $\begin{array}{c}0.00 \\
(0.37)\end{array}$ & $\begin{array}{c}-0.01 \\
(0.23)\end{array}$ \\
\hline Market-to-book & $\begin{array}{c}0.00 \\
(0.20)\end{array}$ & $\begin{array}{c}0.01 \\
(0.01)\end{array}$ & $\begin{array}{c}-0.00 \\
(0.57)\end{array}$ & $\begin{array}{c}0.00 \\
(0.92)\end{array}$ \\
\hline Net leverage & $\begin{array}{c}-0.01 \\
(0.01)\end{array}$ & $\begin{array}{c}-0.00 \\
(0.10)\end{array}$ & $\begin{array}{c}-0.01 \\
(0.01)\end{array}$ & $\begin{array}{c}-0.01 \\
(0.49)\end{array}$ \\
\hline Negative returns & $\begin{array}{r}-0.00 \\
(0.92)\end{array}$ & $\begin{array}{r}-0.00 \\
(0.49)\end{array}$ & $\begin{array}{c}0.01 \\
(0.07)\end{array}$ & $\begin{array}{c}-0.03 \\
(0.16)\end{array}$ \\
\hline Negative earnings & $\begin{array}{c}-0.01 \\
(0.05)\end{array}$ & $\begin{array}{c}-0.01 \\
(0.07)\end{array}$ & $\begin{array}{c}-0.03 \\
(0.03)\end{array}$ & $\begin{array}{c}-0.00 \\
(0.91)\end{array}$ \\
\hline Options outstanding & $\begin{array}{c}0.00 \\
(0.99)\end{array}$ & $\begin{array}{r}-0.00 \\
(0.88)\end{array}$ & $\begin{array}{c}0.00 \\
(0.54)\end{array}$ & $\begin{array}{c}-0.01 \\
(0.01)\end{array}$ \\
\hline Dividend yield & $\begin{array}{c}0.02 \\
(0.51)\end{array}$ & $\begin{array}{c}-0.00 \\
(0.96)\end{array}$ & $\begin{array}{c}0.02 \\
(0.49)\end{array}$ & $\begin{array}{c}0.02 \\
(0.89)\end{array}$ \\
\hline$R O A$ & $\begin{array}{c}0.06 \\
(0.01)\end{array}$ & $\begin{array}{c}0.06 \\
(0.01)\end{array}$ & $\begin{array}{c}0.06 \\
(0.08)\end{array}$ & $\begin{array}{c}-0.03 \\
(0.66)\end{array}$ \\
\hline$\triangle R O A$ & $\begin{array}{c}-0.03 \\
(0.05)\end{array}$ & $\begin{array}{c}-0.02 \\
(0.07)\end{array}$ & $\begin{array}{c}-0.06 \\
(0.17)\end{array}$ & $\begin{array}{c}-0.08 \\
(0.22)\end{array}$ \\
\hline Repurchase & $\begin{array}{c}0.05 \\
(0.01)\end{array}$ & $\begin{array}{l}0.05 \\
(0.01)\end{array}$ & $\begin{array}{c}0.04 \\
(0.01)\end{array}$ & $\begin{array}{c}-0.04 \\
(0.18)\end{array}$ \\
\hline Repurchase $\times$ EPS & $\begin{array}{c}-0.01 \\
(0.30)\end{array}$ & $\begin{array}{c}-0.01 \\
(0.36)\end{array}$ & $\begin{array}{c}-0.01 \\
(0.72)\end{array}$ & $\begin{array}{c}0.06 \\
(0.10)\end{array}$ \\
\hline Intercept & $\begin{array}{c}-0.01 \\
(0.91)\end{array}$ & $\begin{array}{c}-0.01 \\
(0.74)\end{array}$ & $\begin{array}{c}-0.02 \\
(0.32)\end{array}$ & $\begin{array}{c}0.17 \\
(0.44)\end{array}$ \\
\hline Industry effects & Yes & Yes & Yes & Yes \\
\hline Year effects & Yes & Yes & Yes & Yes \\
\hline Likelihood ratio & 1370.16 & 1088.99 & 301.37 & \\
\hline p-value & 0.01 & 0.01 & 0.01 & 0.01 \\
\hline Adjusted $\mathrm{R}^{2}$ & & & & 0.04 \\
\hline n & $\begin{array}{r}1313 \\
214\end{array}$ & $\begin{array}{r}1053 \\
161\end{array}$ & $\begin{array}{r}260 \\
53\end{array}$ & 1312 \\
\hline
\end{tabular}

Two-tailed probability values are reported in parentheses.

All explanatory variables are measured at the beginning of the repurchase year unless otherwise indicated.

(continued on next page) 


\section{TABLE 5 (continued)}

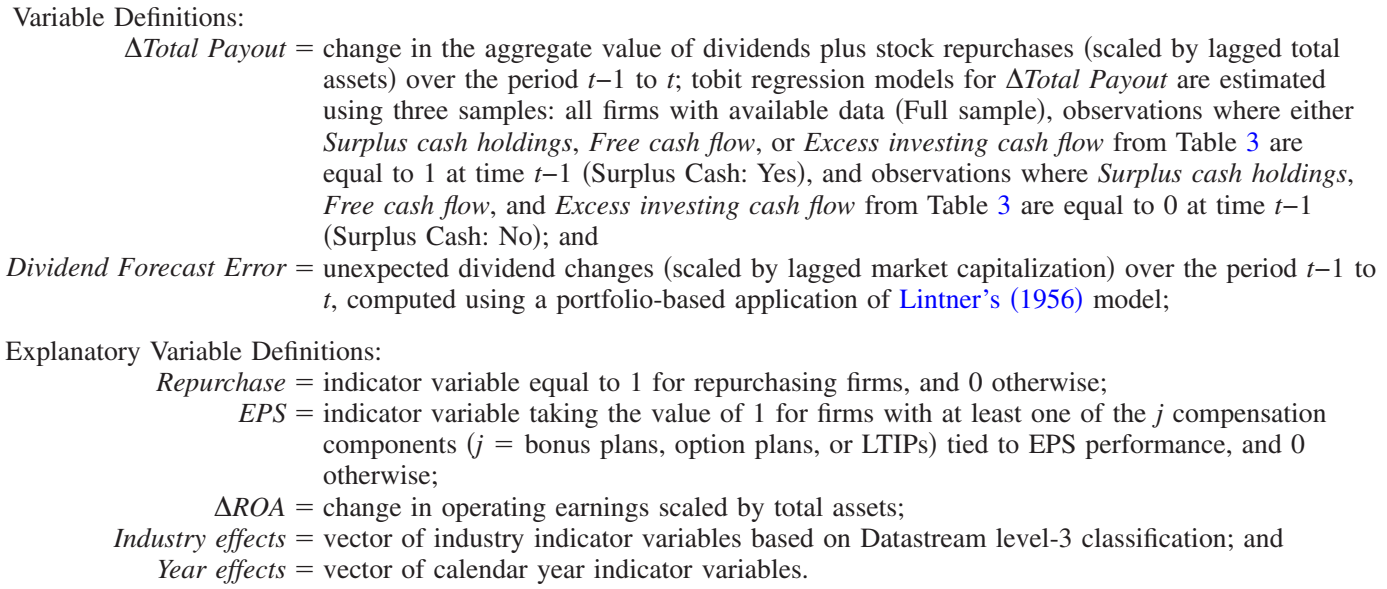

See Tables 2 and 3 for definitions of remaining variables.

associated with significantly larger payout increases for surplus cash flow repurchasers, there is no suggestion of dividend substitution among low cash flow repurchasers with EPS-contingent compensation (column 4).

Our second test of whether EPS targets encourage managers to divert funds from regular dividend increases to pay for repurchases focuses on dividend forecast errors, defined as the observed dividend change minus the expected dividend change. If repurchasers redirect funds from dividend payments to support repurchase activity, then we should observe lower-thanexpected dividend increases in the repurchase year. We draw on Lintner's (1956) model linking current dividends to contemporaneous earnings and lagged dividend payments to estimate expected dividend changes for firm $i$ in year $t$. Because we are unable to estimate firm-specific regression parameters from Lintner's (1956) model due to insufficient time-series data for earnings and dividends, we instead use a portfolio approach based on the following sequential sort procedure. Each year all nonfinancial firms from Extel with available data are sorted into quintiles based on contemporaneous earnings before exceptional items. Each annual earnings portfolio is then further sorted into quintile portfolios according to lagged ordinary dividends. Median annual dividend changes for the resulting 25 earnings-lagged dividend portfolio combinations (computed after excluding repurchasers) serve as estimates of expected dividend changes. Dividend forecast errors are equal to the observed annual dividend change less the median dividend change for firms' corresponding earnings-lagged dividend portfolio in year $t$. Column 5 in Table 5 reports coefficient estimates from an OLS regression of dividend forecast errors on the Repurchase indicator variable, its corresponding interaction with EPS, and a vector of control variables. Although the estimated coefficient on Repurchase is negative, as predicted by the dividend-substitution hypothesis, it is not significant at conventional levels $(\mathrm{p}=0.18)$. Further, the incremental effect for repurchasers with EPS targets (Repurchase $\times E P S$ ) is positive and marginally significant 
$(\mathrm{p}=0.10)$. Overall, results do not support the view that EPS-contingent compensation arrangements motivate firms to divert funds from ordinary dividend payments to support repurchases. ${ }^{10}$

\section{Efficient Contracting}

Linking executive compensation to EPS growth provides management with a means of manipulating reported performance (through repurchases) that can easily be avoided by using alternative accounting metrics such as ROA or growth in operating profit. Why EPS conditions remain popular in executive compensation contracts despite the additional earnings management opportunities such arrangements provide is, therefore, an intriguing question. One possibility is that EPS conditions represent an efficient contracting device that helps align interests of managers and shareholders by incentivizing managers to make decisions that promote shareholder value. Prior research highlights several shareholder benefits associated with repurchases including limiting overinvestment of surplus cash, increasing leverage in firms with inefficient capital structure, and signaling stock price undervaluation (Dittmar 2000). Insofar as EPS targets create incentives to manipulate reported performance by repurchasing stock, EPS-based compensation may provide shareholders with a simple means of motivating executives to distribute surplus cash, increase leverage, and correct underpricing in a timely manner.

Table 6 presents models testing whether the positive association between repurchases and cash is more pronounced for firms with EPS performance conditions in the presence of surplus cash. We create an indicator variable, Surplus cash, taking the value of 1 where Surplus cash holdings, Free cash flow, or Excess investing cash flow from Table 3 is equal to 1, and 0 otherwise. We use Surplus cash to partition the sample before estimating separately for each partition a logistic (left-censored tobit) regression relating the probability (scaled value) of a repurchase to stock and flow measures of cash and their associated interactions with EPS. Estimated coefficients on the Cash holdings $\times E P S, C F O \times E P S$, and $C F I \times E P S$ interactions are positive and significant in columns 3 and 4, where Surplus cash is equal to 1 (except for Cash holdings $\times E P S$ in the logistic model). In contrast, only the $C F O \times E P S$ coefficient (tobit model) is positive and significant in columns 5 and 6, where Surplus cash is equal to 0. On balance, these findings suggest that EPS targets benefit shareholders by creating a stronger link between repurchases and cash performance in the presence of surplus cash.

Table 7 examines the intervening effect of low leverage and undervaluation on the link between repurchases and EPS targets. In Models 1 and 2, we estimate a version of Equation (1) relating the probability of a repurchase to the presence of EPS targets and an underleverage indicator variable. Underleverage takes the value of 1 when net leverage is less than the annual median value for the corresponding Datastream level-4 industry group (computed using the Extel population), and 0 otherwise. Model 1 includes Underleverage as a main effect, while Model 2 includes the Underleverage $\times E P S$ interaction. As predicted, estimated coefficients for the Underleverage main effect are positive and significant in both models, as are the coefficients on EPS. The Underleverage $\times E P S$ variable in Model 2, however, does not load $(\mathrm{p}=0.93)$. Accordingly,

\footnotetext{
${ }^{10}$ In supplementary tests we examined off-diagonal cases based on the predicted probabilities from a pooled version of Model 1 in Table 3. We classified repurchasers with an implied probability $\leq 0.5$ as "unexpected repurchasers" and nonrepurchasers with an implied probability $>0.5$ as "unexpected nonrepurchasers." We compared these cases with observations where the model correctly predicts a repurchase (firm is a repurchaser and the implied probability $>0.5$ ) and a nonrepurchase (firm is a nonrepurchaser and the implied probability $\leq 0.5$ ). We find no evidence that unexpected repurchasers perform worse or make lower payouts than expected repurchasers. These results provide further evidence that EPS-based compensation arrangements do not encourage firms to engage in inconsistently suboptimal repurchase activity. On the other hand, there is some suggestion that unexpected nonrepurchasers perform worse than expected nonrepurchasers, consistent with the view that failure to buy back shares in particular situations imposes agency costs on shareholders (e.g., through overinvestment).
} 
TABLE 6

Coefficient Estimates and Model Summary Statistics for Pooled Logistic (Left-Censored Tobit) Regressions Relating the Probability (Scaled Value) of a Repurchase to the Incidence of EPS-Based Performance Conditions in Executive Compensation Contracts, Conditional on Surplus Cash

\begin{tabular}{|c|c|c|c|c|c|}
\hline \multirow[b]{2}{*}{ Variable } & \multirow[b]{2}{*}{ Predicted Sign } & \multicolumn{2}{|c|}{ Surplus Cash: Yes } & \multicolumn{2}{|c|}{ Surplus Cash: No } \\
\hline & & Logistic & Tobit & Logistic & Tobit \\
\hline Cash holdings & $(+)$ & $\begin{array}{c}-3.63 \\
(0.01)\end{array}$ & $\begin{array}{c}-0.11 \\
(0.01)\end{array}$ & $\begin{array}{c}0.30 \\
(0.68)\end{array}$ & $\begin{array}{c}-0.02 \\
(0.54)\end{array}$ \\
\hline$C F O$ & $(+)$ & $\begin{array}{c}3.63 \\
(0.01)\end{array}$ & $\begin{array}{c}0.14 \\
(0.01)\end{array}$ & $\begin{array}{c}6.88 \\
(0.03)\end{array}$ & $\begin{array}{c}0.18 \\
(0.01)\end{array}$ \\
\hline$C F I$ & $(+)$ & $\begin{array}{c}1.34 \\
(0.01)\end{array}$ & $\begin{array}{c}0.03 \\
(0.04)\end{array}$ & $\begin{array}{c}6.20 \\
(0.09)\end{array}$ & $\begin{array}{c}0.14 \\
(0.08)\end{array}$ \\
\hline Log(Market capitalization) & $(?)$ & $\begin{array}{c}0.07 \\
(0.12)\end{array}$ & $\begin{array}{c}0.00 \\
(0.10)\end{array}$ & $\begin{array}{c}0.52 \\
(0.01)\end{array}$ & $\begin{array}{c}0.01 \\
(0.01)\end{array}$ \\
\hline Market-to-book & $(-)$ & $\begin{array}{c}-0.18 \\
(0.10)\end{array}$ & $\begin{array}{c}0.01 \\
(0.01)\end{array}$ & $\begin{array}{c}-0.68 \\
(0.03)\end{array}$ & $\begin{array}{r}-0.01 \\
(0.48)\end{array}$ \\
\hline Net leverage & $(-)$ & $\begin{array}{c}-1.57 \\
(0.01)\end{array}$ & $\begin{array}{c}-0.02 \\
(0.01)\end{array}$ & $\begin{array}{c}-0.38 \\
(0.01)\end{array}$ & $\begin{array}{c}-0.02 \\
(0.01)\end{array}$ \\
\hline Dividend yield & $(?)$ & $\begin{array}{c}-0.67 \\
(0.53)\end{array}$ & $\begin{array}{c}-0.04 \\
(0.44)\end{array}$ & $\begin{array}{l}29.80 \\
(0.01)\end{array}$ & $\begin{array}{r}-0.03 \\
(0.52)\end{array}$ \\
\hline Negative returns & $(+)$ & $\begin{array}{c}-0.05 \\
(0.75)\end{array}$ & $\begin{array}{c}-0.00 \\
(0.89)\end{array}$ & $\begin{array}{c}0.40 \\
(0.31)\end{array}$ & $\begin{array}{c}0.02 \\
(0.18)\end{array}$ \\
\hline Negative earnings & $(-)$ & $\begin{array}{r}-1.14 \\
(0.01)\end{array}$ & $\begin{array}{c}-0.04 \\
(0.01)\end{array}$ & $\begin{array}{r}-1.13 \\
(0.12)\end{array}$ & $\begin{array}{c}-0.02 \\
(0.32)\end{array}$ \\
\hline Options outstanding & $(+)$ & $\begin{array}{r}-0.02 \\
(0.06)\end{array}$ & $\begin{array}{r}-0.00 \\
(0.35)\end{array}$ & $\begin{array}{c}0.02 \\
(0.77)\end{array}$ & $\begin{array}{c}0.01 \\
(0.47)\end{array}$ \\
\hline NDISC & $(?)$ & $\begin{array}{c}1.23 \\
(0.01)\end{array}$ & $\begin{array}{c}0.03 \\
(0.01)\end{array}$ & $\begin{array}{c}2.27 \\
(0.02)\end{array}$ & $\begin{array}{c}0.07 \\
(0.01)\end{array}$ \\
\hline EPS & $(+)$ & $\begin{array}{c}0.45 \\
(0.09)\end{array}$ & $\begin{array}{c}0.01 \\
(0.91)\end{array}$ & $\begin{array}{c}-0.35 \\
(0.65)\end{array}$ & $\begin{array}{c}0.00 \\
(0.99)\end{array}$ \\
\hline$E P S \times$ Cash holdings & $(+)$ & $\begin{array}{c}0.50 \\
(0.60)\end{array}$ & $\begin{array}{c}0.07 \\
(0.05)\end{array}$ & $\begin{array}{r}-1.39 \\
(0.63)\end{array}$ & $\begin{array}{r}-0.19 \\
(0.01)\end{array}$ \\
\hline$E P S \times C F O$ & $(+)$ & $\begin{array}{c}2.55 \\
(0.06)\end{array}$ & $\begin{array}{c}0.10 \\
(0.05)\end{array}$ & $\begin{array}{c}6.00 \\
(0.13)\end{array}$ & $\begin{array}{c}0.19 \\
(0.05)\end{array}$ \\
\hline$E P S \times C F I$ & $(+)$ & $\begin{array}{c}3.42 \\
(0.01)\end{array}$ & $\begin{array}{c}0.15 \\
(0.01)\end{array}$ & $\begin{array}{c}1.33 \\
(0.76)\end{array}$ & $\begin{array}{c}0.04 \\
(0.71)\end{array}$ \\
\hline Intercept & $(?)$ & $\begin{array}{c}-0.02 \\
(0.96)\end{array}$ & $\begin{array}{c}-0.04 \\
(0.01)\end{array}$ & $\begin{array}{c}-4.09 \\
(0.01)\end{array}$ & $\begin{array}{r}-0.09 \\
(0.01)\end{array}$ \\
\hline Industry & & Yes & Yes & Yes & Yes \\
\hline Year & & Yes & Yes & Yes & Yes \\
\hline Likelihood ratio & & 233.10 & 335.66 & 145.47 & 90.49 \\
\hline $\mathrm{n}$ repurchasers/left-censored & & 553 & 516 & 112 & 149 \\
\hline Pseudo $\mathrm{R}^{2}$ & & 0.26 & & 0.57 & \\
\hline$\%$ classified correctly & & 64.50 & & 69.70 & \\
\hline $\mathrm{n}$ & & 1069 & 1069 & 261 & 261 \\
\hline
\end{tabular}

$\overline{\text { Two tailed probability values are }}$ reported in parentheses. 


\section{TABLE 6 (continued)}

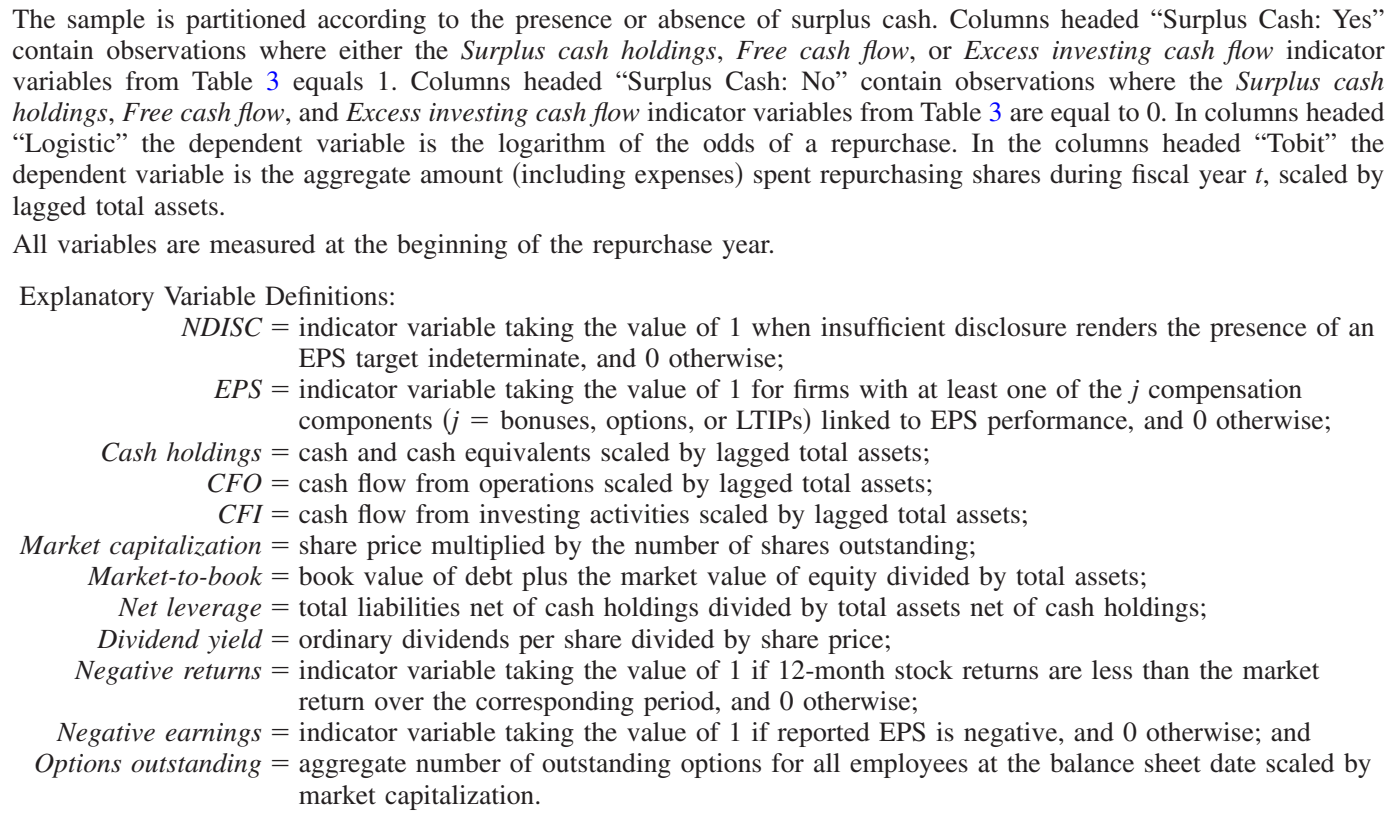

while findings support claims that repurchases are a response to abnormally low leverage, there is no evidence that EPS-based compensation arrangements amplify this effect.

Models 3 and 4 in Table 7 explore the link between equity undervaluation and EPS-motivated repurchases. Our proxy for undervaluation compares observed price with intrinsic value estimated using the harmonic mean of price-to-forward earnings (Liu et al. 2002):

$$
I V_{i t-1}=E_{i t-1}^{F 1} \times \frac{1}{\frac{1}{n} \sum_{j=1}^{J} \frac{E_{j t-1}^{F 1}}{P_{j t-1}}},
$$

where $I V$ is intrinsic value for firm $i$ four months after the beginning of repurchase year $t, E^{F 1}$ is the last available I/B/E/S mean consensus forecast for one-year-ahead EPS during the window -300 days $<t<120$ days, $P$ is observed stock price four months after the end of fiscal year $t$ $-1, J$ is the set of firms with consensus forecast data on $\mathrm{I} / \mathrm{B} / \mathrm{E} / \mathrm{S}$ in the same Datastream level-3 industry as firm $i(i \notin J)$, and $n$ is the number of firms in $J$. The indicator variable Undervaluation takes the value of 1 where $I V_{i t-1}>P_{i t-1}$, and 0 otherwise. Model 3 in Table 7 includes the Undervaluation main effect, while Model 4 is expanded to include the Undervaluation $\times E P S$ term. As with all previous models, EPS loads with a statistically significant positive coefficient in both regressions. The Undervaluation main effect also loads positively in Model 3, suggesting that repurchases are at least a partial response to market mispricing. However, Model 4 suggests this effect is driven by firms with EPS-based compensation conditions: the coefficient on Undervaluation is indistinguishable from 0 , whereas Undervaluation $\times E P S$ is positive and significant at the 10 percent level. (The probability value for a likelihood ratio test comparing Models 3 and 4 is 0.09.) An indication of the economic significance of the interaction effect is provided by compar- 


\section{TABLE 7}

Coefficient Estimates and Model Summary Statistics for Conditional Logistic Regressions Examining the Intervening Effect of Underleverage and Undervaluation on the Association between the Probability of a Repurchase and the Incidence of EPS-Based Performance Conditions in Executive Compensation Contracts

\begin{tabular}{|c|c|c|c|c|c|}
\hline \multirow[b]{2}{*}{ Variables } & \multirow{2}{*}{$\begin{array}{l}\text { Predicted } \\
\text { Sign }\end{array}$} & \multicolumn{2}{|c|}{ Underleverage } & \multicolumn{2}{|c|}{ Undervaluation } \\
\hline & & Model 1 & Model 2 & Model 3 & Model 4 \\
\hline \multirow[t]{3}{*}{ Log(Market capitalization) } & $(?)$ & 1.21 & 1.21 & 1.56 & 1.56 \\
\hline & & 3.34 & 3.35 & 4.74 & 4.76 \\
\hline & & $(0.01)$ & $(0.01)$ & $(0.01)$ & $(0.01)$ \\
\hline \multirow[t]{3}{*}{ Market-to-book } & $(-)$ & -0.67 & -0.68 & -0.67 & -0.67 \\
\hline & & 0.51 & 0.51 & 0.51 & 0.51 \\
\hline & & $(0.01)$ & $(0.01)$ & $(0.01)$ & $(0.01)$ \\
\hline \multirow[t]{3}{*}{ Net leverage } & $(-)$ & & & -0.37 & -0.41 \\
\hline & & & & 0.69 & 0.66 \\
\hline & & & & $(0.10)$ & $(0.07)$ \\
\hline \multirow[t]{3}{*}{ Dividend yield } & $(?)$ & 0.90 & 0.90 & 0.65 & 0.65 \\
\hline & & 2.45 & 2.45 & 1.92 & 1.91 \\
\hline & & $(0.33)$ & $(0.33)$ & $(0.57)$ & $(0.57)$ \\
\hline \multirow[t]{3}{*}{ Negative returns } & $(+)$ & -0.04 & -0.04 & & \\
\hline & & 0.96 & 0.96 & & \\
\hline & & $(0.78)$ & $(0.78)$ & & \\
\hline \multirow[t]{3}{*}{ Negative earnings } & $(-)$ & -1.08 & -1.08 & -1.26 & -1.23 \\
\hline & & 0.34 & 0.34 & 0.28 & 0.29 \\
\hline & & $(0.01)$ & $(0.01)$ & $(0.01)$ & $(0.01)$ \\
\hline \multirow[t]{3}{*}{ Options outstanding } & $(+)$ & -0.02 & -0.02 & 0.01 & 0.01 \\
\hline & & (0.98) & (0.98) & $(1.01)$ & $(1.01)$ \\
\hline & & $(0.12)$ & $(0.12)$ & $(0.75)$ & $(0.71)$ \\
\hline \multirow[t]{3}{*}{ Surplus cash holdings } & $(+)$ & 0.15 & 0.15 & -0.24 & -0.25 \\
\hline & & 1.16 & 1.16 & 0.78 & 0.78 \\
\hline & & $(0.33)$ & $(0.33)$ & $(0.22)$ & $(0.22)$ \\
\hline \multirow[t]{3}{*}{ Free cash flow } & $(+)$ & 0.63 & 0.63 & 0.52 & 0.53 \\
\hline & & 1.87 & 1.87 & 1.67 & 1.69 \\
\hline & & $(0.01)$ & $(0.01)$ & $(0.03)$ & $(0.03)$ \\
\hline \multirow[t]{3}{*}{ Excess investing cash flow } & $(+)$ & 0.72 & 0.72 & 0.83 & 0.83 \\
\hline & & 2.06 & 2.06 & 2.30 & 2.29 \\
\hline & & $(0.01)$ & $(0.01)$ & $(0.01)$ & $(0.01)$ \\
\hline \multirow[t]{3}{*}{ Underleverage } & $(+)$ & 0.42 & 0.40 & & \\
\hline & & 1.52 & 1.49 & & \\
\hline & & $(0.01)$ & $(0.12)$ & & \\
\hline \multirow[t]{3}{*}{ Undervaluation } & $(+)$ & & & 0.76 & 0.10 \\
\hline & & & & 2.13 & 1.11 \\
\hline & & & & $(0.01)$ & $(0.83)$ \\
\hline \multirow[t]{3}{*}{ NDISC } & $(?)$ & 1.46 & 1.46 & 1.70 & 1.85 \\
\hline & & 4.33 & 4.33 & 5.46 & 6.36 \\
\hline & & $(0.01)$ & $(0.01)$ & $(0.01)$ & $(0.01)$ \\
\hline \multirow[t]{3}{*}{$E P S$} & $(+)$ & 0.67 & 0.65 & 0.95 & 0.68 \\
\hline & & 1.95 & 1.92 & 2.57 & 1.98 \\
\hline & & $(0.01)$ & $(0.01)$ & $(0.01)$ & $(0.03)$ \\
\hline
\end{tabular}


TABLE 7 (continued)

\begin{tabular}{|c|c|c|c|c|c|}
\hline \multirow[b]{2}{*}{ Variables } & \multirow{2}{*}{$\begin{array}{l}\text { Predicted } \\
\text { Sign }\end{array}$} & \multicolumn{2}{|c|}{ Underleverage } & \multicolumn{2}{|c|}{ Undervaluation } \\
\hline & & Model 1 & Model 2 & Model 3 & Model 4 \\
\hline$E P S \times$ Underleverage & $(+)$ & & $\begin{array}{c}0.03 \\
1.03 \\
(0.93)\end{array}$ & & \\
\hline EPS $\times$ Undervaluation & $(+)$ & & & & $\begin{array}{c}0.79 \\
2.20 \\
(0.10)\end{array}$ \\
\hline Likelihood ratio & & 267.44 & 268.17 & 207.81 & 210.56 \\
\hline p-value & & 0.01 & 0.01 & 0.01 & 0.01 \\
\hline Pseudo $\mathrm{R}^{2}$ & & 0.44 & 0.44 & 0.50 & 0.51 \\
\hline$\%$ correctly classified & & 73.50 & 73.70 & 78.10 & 78.80 \\
\hline $\mathrm{n}$ & & 665 & 665 & 439 & 439 \\
\hline
\end{tabular}

Three values are reported for each covariate: the first value is the coefficient estimate; the second (italicized) value is the odds ratio; and the third value (in parentheses) is the two-tailed probability value.

The dependent variable is the logarithm of the odds of a repurchase. See Tables 2 and 3 for definitions of all remaining variables. All variables are measured at the beginning of the repurchase year.

Variable Definitions:

$N D I S C=$ indicator variable taking the value of 1 when insufficient disclosure renders the presence of an EPS target indeterminate, and 0 otherwise;

$E P S=$ indicator variable taking the value of 1 for firms with at least one of the $j$ compensation components ( $j=$ bonus plans, option plans, or LTIPs) tied to EPS performance, and 0 otherwise;

Underleverage $=$ indicator variable taking the value of 1 where net leverage is less than the annual median value for the corresponding Datastream level-4 industry group, and 0 otherwise; and

Undervaluation $=$ indicator variable taking the value of 1 where intrinsic value computed using a price-to-forward-earnings multiple is greater than observed price on the valuation date (four months after the beginning of the repurchase year), and 0 otherwise.

ing the odds ratios for Undervaluation in the presence and absence of EPS-contingent contracts. ${ }^{11}$ The odds of repurchasing are no different than the odds of not repurchasing for undervalued firms in the absence of EPS-contingent compensation $\left(e^{0.1}=1.11\right)$. In contrast, the odds of a repurchase are $e^{0.1+0.79}=2.44$ times higher than the odds of not repurchasing for undervalued firms with EPS-contingent compensation. Results provide further (albeit statistically weak) evidence that shareholders benefit from EPS-motivated repurchases in the form of higher buyback probability when stock price falls below intrinsic value.

Our final set of tests examines the interaction between stock repurchases and accrual management. Executives need not resort to repurchases to meet binding EPS targets. Prior research indicates that managers often use accounting accruals to maximize compensation payouts (Healy 1985). Although the choice between alternative earnings management instruments has not been widely explored in the literature, several factors suggest that U.K. shareholders favor EPS management through repurchases over accruals. First, because shareholders benefit from repurchases

${ }^{11}$ Direct interpretation of coefficient estimates and odds ratios reported for interaction terms is problematic in nonlinear models since the effect depends on the contribution of the covariates (Ai and Norton 2003). Comparing odds ratios for the $j$ th covariate in the presence and absence of the $i$ th covariate provides a simple means of interpreting the economic significance of the $j \times i$ interaction. 
(see above), the net impact on shareholder wealth from managing EPS through this method is likely to be less detrimental than accruals, where the gains to shareholders are less obvious. Second, the effect of repurchases on reported EPS is more transparent than accrual choices because U.K. firms must disclose details of all repurchase trades to the stock market without delay and report aggregate repurchase activity in their published financial statements. Investors are therefore better placed to reverse the effect of repurchases on reported EPS, should they wish to do so. Third, unlike accruals that reverse over time, buybacks raise the baseline EPS target permanently and do not contribute to future earnings variability. ${ }^{12}$

If managing EPS through repurchases imposes lower net costs on shareholders relative to accrual manipulation, owners would benefit from compensation-driven buybacks via lower accrual manipulation as executives substitute repurchases for discretionary accruals. We test this prediction by regressing measures of absolute abnormal working capital accruals for the repurchase year on an indicator variable for repurchasers with EPS targets (Repurchase_EPS), the two-way interaction capturing the incremental effect for repurchasers without EPS conditions (Repurchase_EPS $\times N O E P S)$, and a vector of controls. We use the absolute value of abnormal accruals because our prediction relates to the overall level of accrual management activity. ${ }^{13}$

Abnormal working capital accruals are estimated using two methods: the modified-Jones model (Dechow et al. 1995) and the performance-matched model (Kothari et al. 2005). We estimate both models cross-sectionally using industry-year portfolios comprising all observations from Extel with available data. Results in Table 8 are consistent with lower abnormal accrual activity for repurchasers with EPS-contingent compensation arrangements, relative to nonrepurchasers and repurchasers without EPS targets. The estimated coefficient on Repurchase_EPS is negative and significant in all models, while the Repurchase_EPS $\times$ NOEPS coefficient is reliably positive and significant. These findings are consistent with the view that firms with EPS targets are more likely to manipulate reported EPS through repurchases as opposed to working capital accruals. To the extent that manipulation via accruals imposes higher costs on shareholders, these results suggest an additional channel through which the positive association between repurchases and EPS-contingent compensation can benefit shareholders.

\section{Summary}

Results presented in this section suggest net benefits to shareholders from stock repurchases motivated by EPS targets in executive compensation contracts. Repurchasers are associated with larger increases in total payouts, and this effect is no less pronounced for repurchasers with EPS targets, suggesting that dividend substitution is not a first-order concern. Further, the positive link between repurchases and cash performance is more prominent for firms with EPS targets in the presence of surplus cash; undervalued firms with EPS conditions are more likely to signal their

\footnotetext{
${ }^{12}$ Managers may also favor repurchases over accruals as a means of inflating EPS for several reasons. First, because stock market investors typically view repurchases favorably, they are less likely to question executives' underlying repurchases motives. Second, executives can provide convincing, non-manipulation-based explanations to support their actions if challenged by shareholders.

${ }^{13}$ Using a levels approach to model absolute abnormal accruals introduces the risk of spurious correlation. Our results and conclusions should be interpreted with this caveat in mind. Several factors militate against using a changes specification however. First, accrual reversals confound a changes specification: absolute abnormal accrual levels may remain similar over short intervals even when the level of accrual management declines (because high absolute accruals capture both contemporaneous accrual management and unwinding of accrual management from previous periods). Second, if firms use repurchases instead of accruals in response to a new stimulus for EPS manipulation, then absolute accruals will remain constant over time and a changes specification will yield null results. Consistent with these arguments, when we model the change in absolute accruals we find no difference between repurchasers with EPS conditions, repurchasers without EPS conditions, and nonrepurchasers.
} 
TABLE 8

Coefficient Estimates and Model Summary Statistics from Pooled OLS Regressions Relating Absolute Abnormal Accrual Activity to Repurchase Activity and a Vector of Control Variables

\begin{tabular}{|c|c|c|c|c|c|}
\hline \multirow[b]{3}{*}{ Variable } & \multirow{3}{*}{$\begin{array}{l}\text { Predicted } \\
\text { Sign }\end{array}$} & \multicolumn{4}{|c|}{$\begin{array}{l}\text { Absolute Abnormal Accruals Computed } \\
\text { Using: }\end{array}$} \\
\hline & & \multicolumn{2}{|c|}{ DSS Model } & \multicolumn{2}{|c|}{ KLW Model } \\
\hline & & Model 1 & Model 2 & Model 1 & Model 2 \\
\hline Log(Total assets) & $(?)$ & & $\begin{array}{c}0.00 \\
(0.19)\end{array}$ & & $\begin{array}{c}0.00 \\
(0.04)\end{array}$ \\
\hline Market-to-book & $(?)$ & & $\begin{array}{c}0.00 \\
(0.29)\end{array}$ & & $\begin{array}{c}0.00 \\
(0.14)\end{array}$ \\
\hline Net leverage & $(+)$ & & $\begin{array}{c}0.01 \\
(0.01)\end{array}$ & & $\begin{array}{c}0.01 \\
(0.01)\end{array}$ \\
\hline Negative earnings & $(+)$ & & $\begin{array}{c}0.01 \\
(0.14)\end{array}$ & & $\begin{array}{c}0.01 \\
(0.52)\end{array}$ \\
\hline Options outstanding & $(+)$ & & $\begin{array}{c}0.00 \\
(0.24)\end{array}$ & & $\begin{array}{c}0.00 \\
(0.11)\end{array}$ \\
\hline oOperating cash flow & $(+)$ & & $\begin{array}{c}0.18 \\
(0.01)\end{array}$ & & $\begin{array}{c}0.20 \\
(0.01)\end{array}$ \\
\hline Lagged absolute accruals & $(+)$ & & $\begin{array}{c}0.05 \\
(0.01)\end{array}$ & & $\begin{array}{c}0.05 \\
(0.01)\end{array}$ \\
\hline Repurchase_EPS & $(-)$ & $\begin{array}{c}-0.02 \\
(0.01)\end{array}$ & $\begin{array}{c}-0.02 \\
(0.02)\end{array}$ & $\begin{array}{c}-0.02 \\
(0.01)\end{array}$ & $\begin{array}{c}-0.01 \\
(0.04)\end{array}$ \\
\hline Repurchase_EPS $\times$ NOEPS & $(+)$ & $\begin{array}{c}0.02 \\
(0.05)\end{array}$ & $\begin{array}{c}0.02 \\
(0.05)\end{array}$ & $\begin{array}{c}0.02 \\
(0.02)\end{array}$ & $\begin{array}{c}0.02 \\
(0.05)\end{array}$ \\
\hline Intercept & $(?)$ & $\begin{array}{c}0.10 \\
(0.01)\end{array}$ & $\begin{array}{c}0.09 \\
(0.01)\end{array}$ & $\begin{array}{c}0.10 \\
(0.01)\end{array}$ & $\begin{array}{c}0.09 \\
(0.01)\end{array}$ \\
\hline Industry & & No & Yes & No & Yes \\
\hline Year & & No & Yes & No & Yes \\
\hline Adjusted-R ${ }^{2}$ & & 0.01 & 0.09 & 0.01 & 0.07 \\
\hline p-value & & 0.01 & 0.01 & 0.01 & 0.01 \\
\hline $\mathrm{n}$ & & 1314 & 1312 & 1314 & 1312 \\
\hline $\mathrm{n}$ repurchasers & & 656 & 654 & 656 & 654 \\
\hline
\end{tabular}

Two-tailed probability values are reported in parentheses. The dependent variable is the absolute value of abnormal working capital accruals, where abnormal accruals are the residual from either the Dechow et al. (1995) working capital accrual model (DDS) or the Kothari et al. (2005) working capital accrual model (KLW). Both accrual models are estimated cross-sectionally for all industry-year combinations.

All variables relate to repurchase year $t$.

Variable Definitions:

Repurchase_EPS = indicator variable equal to 1 for repurchasing firms with at least one of the $j$ compensation components $(j=$ bonus plans, option plans, or LTIPs) tied to EPS performance, and 0 otherwise;

NOEPS $=$ indicator variable taking the value of 1 for firms that do not have at least one of the $j$ compensation components tied to EPS performance, and 0 otherwise;

Total assets $=$ balance sheet value of aggregate assets;

Market-to-book $=$ book value of debt plus the market value of equity divided by total assets;

Net leverage $=$ total liabilities net of cash holdings divided by total assets net of cash holdings;

(continued on next page) 


\title{
TABLE 8 (continued)
}

\author{
Negative earnings $=$ indicator variable taking the value of 1 if reported earnings per share are negative, and 0 \\ otherwise; \\ Options outstanding $=$ aggregate number of outstanding options for all employees at the balance sheet date scaled by \\ market capitalization; \\ oOperating Cash flow $=$ standard deviation of operating cash flow scaled by lagged total assets computed over the \\ three-year period centered on year $t$ \\ Lagged accruals $=$ one-year lagged value of the dependent variable; \\ Industry $=$ vector of industry indicator variables based on Datastream level-3 classification; and \\ Year $=$ vector of calendar year indicator variables.
}

undervaluation through a repurchase; and repurchasers with EPS conditions are associated with lower abnormal accruals. We find no evidence that EPS-driven repurchases impose costs on shareholders in the form of investment myopia.

\section{CONCLUSIONS}

This study examines the impact on firms' stock repurchase activity of EPS performance conditions in executive compensation contracts. Our analysis connects three distinct literatures. One body of research demonstrates how aspects of corporate payout policy are sensitive to executives' compensation arrangements. Another body of work based on surveys and anecdotal evidence indicates that managers are sensitive to the EPS impact of repurchases. A third group of studies concludes that managers use repurchases to achieve key EPS performance thresholds. Our analysis integrates these three literatures by examining how repurchase policy is shaped by contractual arrangements that create an explicit link between executive compensation and reported EPS.

We find that EPS targets explain firm-level repurchase policy after controlling for traditional determinants of buybacks. Further analysis reveals that EPS-motivated repurchases yield net benefits to shareholders. Contrary to Bens et al. (2002), we find no evidence that EPS-driven repurchases lead to investment myopia. Instead, repurchasers are associated with larger payout increases to shareholders that partly reflect a more pronounced link between repurchases and cash performance for firms with EPS targets in the presence of surplus cash flow. In addition, undervalued firms with EPS targets are more likely to signal mispricing through a repurchase, and repurchasers with EPS conditions are associated with lower abnormal accrual activity.

With repurchases emerging as a key payout mechanism in many jurisdictions and in view of concerns about the motives underlying this trend (Bens et al. 2002; Bens et al. 2003; Hribar et al. 2006; Marquardt et al. 2009), a better understanding of the contractual incentives driving repurchase activity and their associated economic consequences is appropriate. Our findings reveal significant contracting benefits from the repurchase incentives that result from linking executive compensation to EPS. In particular, we identify stock repurchases as a potentially important benefit of EPS-based targets in executive compensation contracts that improves alignment of managers' and shareholders' interests. This insight is consistent with Huang et al. (2010) who find that EPS-based bonus plans help to address agency conflicts between managers and shareholders in the form of ownership dilution. We therefore provide a modest further step toward a more complete understanding of the costs and benefits associated with per-share-based performance measures in general, and in particular why EPS-based targets remain a popular choice in executive compensation contracts despite their obvious limitations. 


\section{REFERENCES}

Aboody, D., and R. Kasznik. 2008. Executive stock-based compensation and firms' cash payout: The role of shareholders' tax-related payout preferences. Review of Accounting Studies 13 (2-3): 216-251.

Ai, C., and E. Norton. 2003. Interaction terms in logit and probit models. Economics Letters 80 (1): 123-129.

Allison, P. 1999. Logistic Regression Using the SAS ${ }^{\circledR}$ System: Theory and Application. Cary, NC: SAS Institute Inc.

Antle, R., and A. Smith. 1986. An empirical investigation of the relative performance evaluation of corporate executives. Journal of Accounting Research 24 (1): 1-39.

Badrinath, S., and N. Varaiya. 2000. The Share Repurchase Decision: Causes, Consequences, and Implementation Guidelines. Morristown, NJ: Financial Executives Research Foundation.

Bens, D., V. Nagar, D. Skinner, and F. Wong. 2003. Employee stock options, EPS dilution, and stock repurchases. Journal of Accounting and Economics 36 (1-3): 51-90.

Bens, D., V. Nagar, and F. Wong. 2002. Real investment implications of employee stock option exercises. Journal of Accounting Research 40 (2): 359-393.

Brav, A., J. Graham, and C. Harvey. 2005. Payout policy in the 21st century. Journal of Financial Economics 77 (3): 483-527.

Brealey, R., S. Myers, and F. Allen. 2008. Principles of Corporate Finance. 9th edition. New York, NY: McGraw-Hill.

Bushman, R., and A. Smith. 2001. Financial accounting information and corporate governance. Journal of Accounting and Economics 32 (1-3): 237-333.

Carter, M. E., C. Ittner, and S. Zechman. 2009. Explicit relative performance evaluation in performancevested equity grants. Review of Accounting Studies 14 (2-3): 269-306.

Caster, A. B., R. J. Elson, and L. G. Weld. 2006. Is diluted EPS becoming more art than fact? The CPA Journal 76 (9): 26-29.

Cohen, D., A. Dey, and T. Lys. 2008. Real and accrual-based earnings management in the pre- and postSarbanes Oxley periods. The Accounting Review 83 (3): 757-787.

Conyon, M., and K. Murphy. 2000. The prince and the pauper? CEO pay in the U.S. and U.K. The Economic Journal 110 (467): 640-671.

Conyon, M., S. Peck, L. Read, and G. Sadler. 2000. The structure of executive compensation contracts: U.K. evidence. Long Range Planning 33 (4): 478-503.

Dechow, P., R. Sloan, and A. Sweeney. 1995. Detecting earnings management. The Accounting Review 70 (2): 193-225.

Demski, J., H. Frimor, and D. Sappington. 2004. Efficient manipulation in a repeated setting. Journal of Accounting Research 42 (1): 31-49.

Dittmar, A. 2000. Why do firms repurchase stock? The Journal of Business 73 (3): 331-355.

Easterbrook, F. 1984. Two agency-cost explanations of dividends. The American Economic Review 74 (4): 650-659.

Fenn, G., and N. Liang. 2001. Corporate payout policy and managerial stock incentives. Journal of Financial Economics 60 (1): 45-72.

Greenbury Report. 1995. Directors' Remuneration. Report of a Study Group Chaired by Sir Richard Greenbury. London, U.K.: Gee Publishing Ltd.

Grullon, G., and R. Michaely. 2002. Dividends, share repurchases, and the substitution hypothesis. The Journal of Finance 57 (4): 1649-1684.

Guay, W. 2002. Discussion of: Real investment implications of employee stock option exercises. Journal of Accounting Research 40 (2): 395-406.

, and J. Harford. 2000. The cash flow permanence and information content of dividend increases vs. repurchases. Journal of Financial Economics 57 (3): 385-415.

Healy, P. 1985. The effect of bonus schemes on accounting decisions. Journal of Accounting and Economics 7 (1-3): 85-107.

Hribar, P., N. Jenkins, and W. B. Johnson. 2006. Stock repurchases as an earnings management device. Journal of Accounting and Economics 41 (1-2): 3-27. 
Huang, R., C. Marquardt, and B. Zhang. 2010. Why do managers avoid EPS dilution? Presented at the 2010 Journal of Accounting Research Conference; Working paper, City University of New York. Available at SSRN: http://ssrn.com/abstract $=1464496$.

Jagannathan, M., C. Stephens, and M. Weisbach. 2000. Financial flexibility and the choice between dividends and stock repurchases. Journal of Financial Economics 57 (3): 355-384.

Kahle, K. 2002. When a buyback isn't a buyback: Open market repurchases and employee options. Journal of Financial Economics 63 (2): 235-261.

Kothari, S. P., A. J. Leone, and C. E. Wasley. 2005. Performance matched discretionary accrual models. Journal of Accounting and Economics 39 (1): 163-197.

Lambert, R., W. Lanen, and D. Larcker. 1989. Executive stock option plans and corporate dividend policy. Journal of Financial and Quantitative Analysis 24 (4): 409-425.

Lintner, J. 1956. Distribution of incomes of corporations among dividends, retained earnings, and taxes. The American Economic Review 46 (2): 97-113.

Liu, J., D. Nissim, and J. Thomas. 2002. Equity valuation using multiples. Journal of Accounting Research 40 (1): 135-172.

Marquardt, C., C. Tan, and S. Young. 2009. Accelerated share repurchases, bonus contracts, and CEO horizons. Working paper, City University of New York. Available at: http://ssrn.com/abstract $=1346624$.

Murphy, K. 1999. Executive compensation. In Handbook of Labor Economics, Vol. 3, edited by O. Ashenfelter and D. Card., 2485-2563, Amsterdam, The Netherlands: Elsevier Science North.

Myers, J., L. Myers, and D. Skinner. 2007. Earnings momentum and earnings management. Journal of Accounting, Auditing \& Finance 22 (2): 249-284.

Opler, T., L. Pinkowitz, R. Stulz, and R. Williamson. 1999. The determinants and implications of corporate cash holdings. Journal of Financial Economics 52 (1): 3-46.

— and S. Titman. 1993. The determinants of leveraged buyout activity: Free cash flows vs. financial distress costs. The Journal of Finance 48 (5): 1985-1999.

Pass, C., A. Robinson, and D. Ward. 2000. Performance criteria of corporate option and long-term incentive plans: A survey of 150 U.K. companies 1994-1998. Management Decision 38 (2): 130-137.

Prentice, R., and R. Pyke. 1979. Logistic disease incidence models and case-control studies. Biometrika 66 (3): 403-411.

Smith, C., and R. Watts. 1992. The investment opportunity set and corporate financing, dividend, and compensation policies. Journal of Financial Economics 32 (3): 263-292.

Stephens, C., and M. Weisbach. 1998. Actual share reacquisitions in open market repurchase programs. The Journal of Finance 53 (1): 313-333.

Vermaelen, T. 1981. Common stock repurchases and market signaling: An empirical study. Journal of Financial Economics 9 (2): 139-183.

Wallace, J. 1997. Adopting residual income-based compensation plans: Do you get what you pay for? Journal of Accounting and Economics 24 (3): 275-300.

White, L. 1996. Executive compensation and dividend policy. Journal of Corporate Finance 2 (4): 335-358. 